\title{
A worldwide molecular phylogeny and classification of the leafy spurges, Euphorbia subgenus Esula (Euphorbiaceae)
}

\author{
Ricarda Riina, ${ }^{1,2}$ Jess A. Peirson, ${ }^{1}$ Dmitry V. Geltman, ${ }^{3}$ Julián Molero, ${ }^{4}$ Božo Frajman, ${ }^{5}$ \\ Amirhossein Pahlevani, ${ }^{6,7}$ Laia Barres, ${ }^{8}$ Jeffery J. Morawetz, ${ }^{9}$ Yasaman Salmaki, ${ }^{10}$ Shahin Zarre, ${ }^{10}$ \\ Aleksey Kryukov, ${ }^{3}$ Peter V. Bruyns ${ }^{11}$ \& Paul E. Berry ${ }^{1}$ \\ 1 Department of Ecology and Evolutionary Biology, University of Michigan, 830 North University Avenue, Ann Arbor, \\ Michigan 48109-1048, U.S.A. \\ 2 Real Jardín Botánico, RJB-CSIC, Plaza de Murillo 2, 28014 Madrid, Spain \\ 3 Komarov Botanical Institute of the Russian Academy of Sciences, 2 Prof. Popov Street, St. Petersburg, 197376, Russia \\ 4 Laboratori de Botànica, Facultat de Farmàcia, Universitat de Barcelona, Avda. Joan XXIII s.n., 08028 Barcelona, Spain \\ 5 Institute of Botany, University of Innsbruck, Sternwartestrasse 15, 6020 Innsbruck, Austria \\ 6 Department of Plant Systematics, University of Bayreuth, 95440 Bayreuth, Germany \\ 7 Department of Botany, Iranian Research Institute of Plant Protection, P.O. Box 1454, Tehran 19395, Iran \\ 8 Institut Botànic de Barcelona (CSIC-ICUB), Pg. del Migdia s.n., 08038 Barcelona, Spain \\ 9 Rancho Santa Ana Botanic Garden, 1500 North College Ave., Claremont, California 91711-3157, U.S.A. \\ 10 Center of Excellence in Phylogeny of Living Organisms, Department of Plant Science, School of Biology, College of Science, \\ University of Tehran, P.O. Box 14155-6455, Tehran, Iran \\ 11 Bolus Herbarium, University of Cape Town, Rondebosch 7701, South Africa \\ Author for correspondence: Paul E.Berry, peberry@umich.edu
}

\begin{abstract}
The leafy spurges, Euphorbia subg. Esula, make up one of four main lineages in Euphorbia. The subgenus comprises about 480 species, most of which are annual or perennial herbs, but with a small number of dendroid shrubs and nearly leafless, pencil-stemmed succulents as well. The subgenus constitutes the primary northern temperate radiation in Euphorbia. While the subgenus is most diverse from central Asia to the Mediterranean region, members of the group also occur in Africa, in the Indo-Pacific region, and in the New World. We have assembled the largest worldwide sampling of the group to date (273 spp.), representing most of the taxonomic and geographic breadth of the subgenus. We performed phylogenetic analyses of sequence data from the nuclear ribosomal ITS and plastid $n d h F$ regions. Our individual and combined analyses produced well-resolved phylogenies that confirm many of the previously recognized clades and also establish a number of novel groupings and placements of previously enigmatic species. Euphorbia subg. Esula has a clear Eurasian center of diversity, and we provide evidence for four independent arrivals to the New World and three separate colonizations of tropical and southern Africa. One of the latter groups further extends to Madagascar and New Zealand, and to more isolated islands such as Réunion and Samoa. Our results confirm that the dendroid shrub and stem-succulent growth forms are derived conditions in E. subg. Esula. Stemsucculents arose twice in the subgenus and dendroid shrubs three times. Based on the molecular phylogeny, we propose a new classification for E. subg. Esula that recognizes 21 sections (four of them newly described and two elevated from subsectional rank), and we place over $95 \%$ of the accepted species in the subgenus into this new classification.
\end{abstract}

Keywords biogeography; Euphorbia subg. Esula; ITS; leafy spurges; molecular phylogeny; $n d h F$

Supplementary Material The Electronic Supplement (Figs. S1-S3, Appendix S1) and the alignment files are available in the Supplementary Data section of the online version of this article (http://ingentaconnect.com/content/iapt.tax).

Received: 11 Sep. 2012; revision received: 7 Dec. 2012; accepted: 2 Feb. 2013.

\section{INTRODUCTION}

Recent molecular phylogenetic studies of Euphorbia L. (Euphorbiaceae) have greatly refined and improved our understanding of infrageneric relationships within this worldwide genus of over 2000 species. Four major clades (A-D) were identified in the first phylogenetic investigation of Euphorbia by Steinmann \& Porter (2002). These clades were later formalized by Bruyns \& al. (2006) as four subgenera: E. subg.
Rhizanthium (Boiss.) Wheeler, E. subg. Esula Pers., E. subg. Euphorbia, and E. subg. Chamaesyce Raf., respectively. We just recently discovered, however, that there is an earlier name available for $E$. subg. Rhizanthium, namely $E$. subg. Athymalus Neck. ex Rchb. (Peirson \& al., in prep.), so we will be using this name now to replace $E$. subg. Rhizanthium. More recent studies by Park \& Jansen (2007), Zimmerman \& al. (2010), and Bruyns \& al. (2011) corroborated the four-clade structure within the genus and indicated that E. subg. Esula is sister to 
the other three subgenera. Horn \& al. (2012) analyzed data from ten molecular markers from all three plant genomes, with a broad taxon sampling of species across Euphorbia. This study produced a well-supported backbone topology confirming that E. subg. Esula was sister to the other three subgenera, with E. subg. Athymalus sister in turn to E. subg. Euphorbia and E. subg. Chamaesyce (Fig. 1). More in-depth studies investigating species-level relationships and proposing sectional classifications within E. subg. Chamaesyce and E. subg. Euphorbia have been completed (Yang \& al., 2012; Dorsey \& al., 2013), and a study of $E$. subg. Athymalus is in preparation.

The present study focuses on the phylogeny and classification of Euphorbia subg. Esula. This subgenus consists of about 480 species and represents the most significant radiation of the genus in temperate areas of the Old World. We use the term "leafy spurge" here in a broad context (as opposed to the more restricted use that refers mainly to the invasive E. virgata and related species) to refer to any plant in $E$. subg. Esula, given that leafy herbaceous plants are the predominant growth form in the subgenus. The subgenus has a nearly worldwide distribution (absent from Australia and Antarctica) but is most diverse in temperate Eurasia, particularly in the Mediterranean and the Irano-Turanian regions. The group also occurs in Macaronesia, Africa, the Arabian Peninsula, Southeast Asia, and the islands of Madagascar, Réunion, New Zealand, and Samoa. In the New World it is mainly found in Mexico and the United States. The leafy spurges are the most uniform of the four subgenera of Euphorbia in terms of their diversity of growth forms and overall morphology. Most species are characterized by having well-developed leaves; a lack of stipules; cyathia arranged in cymose rays around a terminal cyathium, with the rays further divided into dichasial branches; involucral glands that are entire, crenate, or with horn-like but never petaloid appendages; and carunculate seeds (Figs. 2, 3). Although most of the species in E. subg. Esula are leafy, annual or perennial herbs (Fig. 2A, B), there are also several small radiations of leafy but mostly deciduous, dendroid shrubs (Fig. 2D) and leafless, pencil-stemmed succulent shrubs (Fig. 2C). We employ the term "dendroid" here to refer to plants that have a characteristic woody habit, usually with a stout basal trunk that soon branches extensively and tends to form a hemispheric crown. The term has historical precedence (viz., Linnaeus, 1753; Boissier, 1862) and has also been used in recent studies such as Molero \& al. (2002) and Barres \& al. (2011).

The leafy spurges occupy a wide array of habitats including deserts, coastal dunes, steppe grasslands, shrublands and forests, riparian areas, rocky slopes, and cliffs. Several occur in disturbed areas as weeds. Elevations at which they are found range from sea level to over $4000 \mathrm{~m}$. A number of species have become naturalized outside of their native ranges, and $E u$ phorbia virgata (usually confused with $E$. esula) can be a particularly noxious weed where it has been introduced in North America (DiTomaso \& Healy, 2007). There are also species in this subgenus that are cultivated and used as ornamentals, such as the semisucculent $E$. characias (Mediterranean spurge) and $E$. myrsinites (myrtle spurge). Leafy spurges are rich in diterpenoid compounds that are responsible for both the irritant effect of their latex and the medicinal uses of some species (Hartwell, 1969; Giner \& al., 2000; Schmelzer \& Gurib-Fakim, 2008; Ramsay \& al., 2011).

Historically, the circumscription of Euphorbia subg. Esula has differed considerably among authors. Boissier (1862) placed most members of the subgenus into $E$. sect. Tithymalus (Gaertn.) Roep., but his concept of that large section also included species or subsections that have now been shown to belong to one of the other three subgenera of Euphorbia (Steinmann \& Porter, 2002; Horn \& al., 2012; Yang \& al., 2012; Dorsey \& al., 2013). Conversely, the twelve leafless, pencil-stemmed shrubby species that are now known to belong to E. subg. Esula, such as E. aphylla, were previously included in a broadly defined group called E. subg. Tirucalli (Boiss.) S. Carter (e.g., Carter, 2002) that has since been shown through molecular evidence to be a polyphyletic assemblage of pencil-stemmed succulents, with members in each of the four subgenera (Steinmann \& Porter, 2002; Bruyns \& al., 2006, 2011; Barres \& al., 2011; Horn \& al., 2012). A better approximation to our present understanding of E. subg. Esula was Prokhanov's (1949) concept of $E$. subg. Paralias (Raf.) Prokh., which he further subdivided into a number of sections, subsections, and series. Prokhanov (1964) later recognized his E. subg. Paralias as a synonym of E. subg. Esula. The recent molecular studies of Frajman \& Schönswetter (2011) and Kryukov \& al. (2010) only partly agreed with Prokhanov's sectional circumscriptions, however, and showed that annual species evolved many times in E. subg. Esula and did not form discrete monophyletic groups as Prokhanov had implied. Frajman \& Schönswetter (2011) recognized eleven sections in

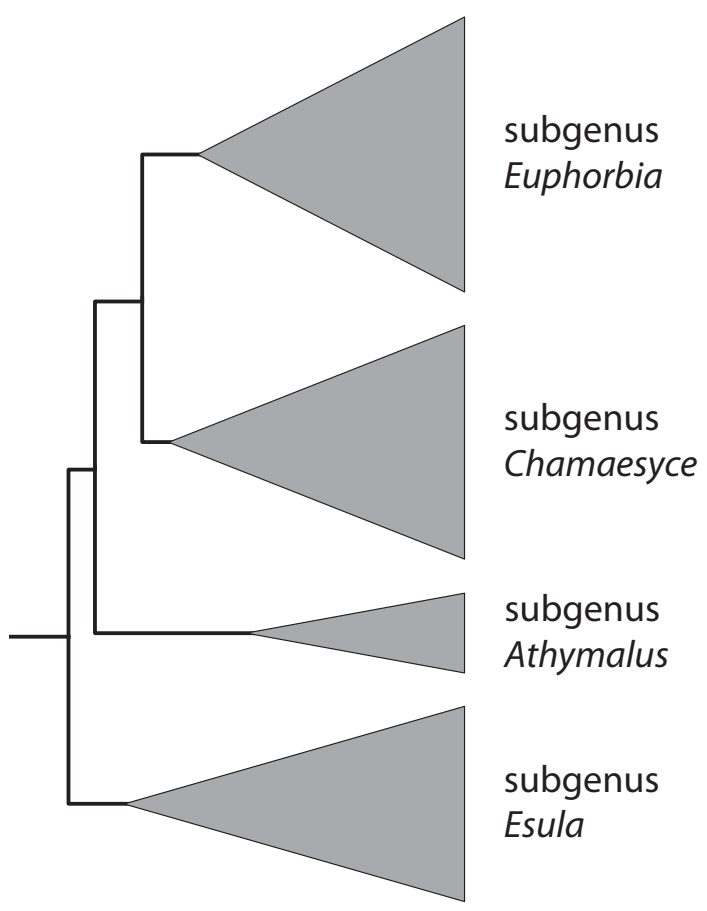

Fig. 1. Schematic representation of Euphorbia subgeneric topology (after Horn \& al., 2012). The four subgenera are represented by filled triangles whose vertical axes are scaled to reflect the number of species in each. Euphorbia subg. Rhizanthium has been changed to E. subg. Athymalus, an earlier name for the same group. 


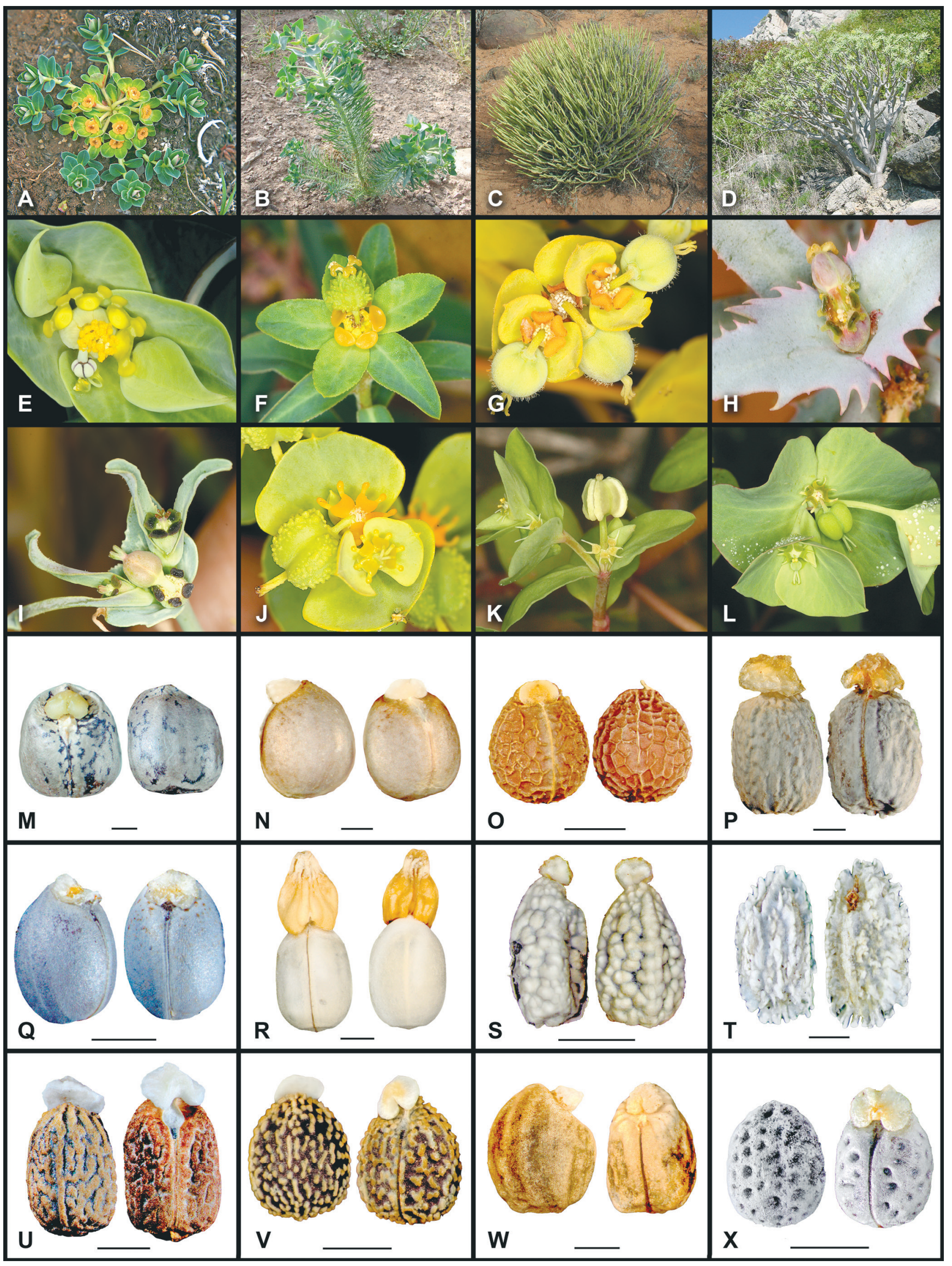


E. subg. Esula, but they focused primarily on European species and did not sample the rich diversity in Asia and on other continents. To date, there has been no comprehensive molecular phylogenetic study with sufficient taxonomic and geographic coverage to develop a worldwide classification encompassing all lineages within $E$. subg. Esula.

With the creation of the Euphorbia Planetary Biodiversity Inventory project in 2006 (Esser \& al., 2009; Riina \& Berry, 2012a), we convened the leading experts on leafy spurges worldwide and worked together to assemble a broad taxonomic

Fig. 2. Euphorbia subg. Esula: A-D, representative growth forms; E-L, fruit types and cyathial gland appendages; $\mathbf{M}-\mathbf{X}$, seed types (scale bars $=1 \mathrm{~mm}$ ). A, Euphorbia stracheyi, a perennial herb in E. sect. Holophyllum; B, E. aleppica, the only annual herb in E. sect. Myrsiniteae; C, E. mauritanica, a nearly leafless, pencil-stemmed, succulent shrub in E. sect. Aphyllis; D, E. pedroi, a semisucculent dendroid shrub in E. sect. Aphyllis; E, E. lathyris, oval cyathial glands with knoblike appendages, in E. sect. Lathyris; F, E. flavicoma, warty fruits and cyathial glands without appendages, in E. sect. Helioscopia; G, E. nicaeensis, with smooth, hairy ovaries and trapezoidal, unappendaged cyathial glands, in E. sect. Pithyusa; H, E. retusa, green cyathial glands with short appendages, smooth ovary, and serrate subcyathial raylet leaves, in E. sect. Chylogala; I, E. calyptrata, with unappendaged cyathial glands, smooth ovary, and finely serrate subcyathial raylet leaves, in E. sect. Calyptratae; J, E. briquetii, with verrucose ovaries and two claviform gland appendages, in E. sect. Biumbellatae; K, E. peplus, with shortly winged capsules and glands with narrow, horn-like appendages, in E. sect. Tithymalus; L, E. emirnen$s i s$, with smooth ovary and semilunate glands with horn-like appendages, in E. sect. Esula; M, E. wallichii, with smooth, mottled grayblack seeds, in E. sect. Holophyllum; N, E. purpurea, with smooth, shiny brown seeds, in E. sect. Helioscopia; 0, E. helioscopia, with foveolate seed surface, in E. sect. Helioscopia; $\mathbf{P}$, E. oxyphylla, with rugulose, grayish seeds, in E. sect. Myrsiniteae; Q, E. seguieriana, with smooth grayish seeds, in E. sect. Pithyusa; R, E. retusa, with smooth whitish seeds and a large apical caruncle, in $E$. sect. Chylogala; $\mathbf{S}, E$. densa, with tuberculate seed surface, in E. sect. Herpetorrhizae; $\mathbf{T}$, E. guyoniana, with ecarunculate seeds covered by a spongy covering with denticulate-lacerate wings, in E. sect. Guyonianae; U, $E$. biumbellata, with vermiculate seed surface, in $E$. sect. Biumbellatae; $\mathbf{V}$, E. medicaginea, with vermiculiform-tuberculate seed surface, in E. sect. Exiguae; W, E. berotica, with tuberculate-rugose seed surface, in E. sect. Aphyllis; X, E. commutata, with regularly pitted seed surface, in E. sect. Tithymalus. - Photo credits: A: A. Reznicek; B: Y. Salmaki; C, E, L, S: P. Berry; D: R. van Veldhuisen; F-K: R. Riina; M-R, T-X: B. Wagner \& J. Morawetz. Composition by K. Elliot.

Fig. 3. Diagram of a basic synflorescence in Euphorbia subg. Esula. The labels reflect the terminology used in this paper, with alternative terms in parentheses: stem leaves (cauline leaves), axillary vegetative shoot (infertile branch), axillary ray (fertile branch, axillary cymose branch, infra-umbellary ray), synflorescence (incyathescence), pleiochasium (pseudopleiochasium, pleiochasial cyme, terminal pleiochasium, pseudoumbel, umbel-like cyme, umbellaster, apical synflorescence), ray leaves (pleiochasial bracts, involucral leaves), terminal rays (pleiochasial branches, apical rays, terminal umbellate rays, primary umbellate rays), dichasium, raylet leaves (dichasial bracts, involucellar leaves), subcyathial raylet leaves (subcyathial bracts, cyathophylls), and cyathium. and geographic sampling of species in E. subg. Esula. We set out to: (1) build a robust molecular phylogeny that would allow us to examine evolutionary relationships within Euphorbia subg. Esula; (2) develop a section-level classification based upon the phylogeny; (3) infer sectional membership of still unsampled species from their morphological characters and geographic distribution; and (4) begin to understand the biogeographic and morphological evolution within the subgenus.

\section{MATERIALS AND METHODS}

Taxon and molecular sampling. - We sampled 273 species (283 taxa) within Euphorbia subg. Esula, aiming to cover most of the previously recognized infrasubgeneric taxonomic groups and the geographical distribution of the subgenus. Our outgroup sampling included 17 species from the remaining three subgenera of Euphorbia (five in E. subg. Chamaesyce, five in E. subg. Euphorbia, and seven in E. subg. Athymalus), as well as Neoguillauminia cleopatra and Calycopeplus casuarinoides. Voucher information and GenBank accession numbers for all sequences used in our analyses are listed in Appendix S1 (Electr. Suppl.).

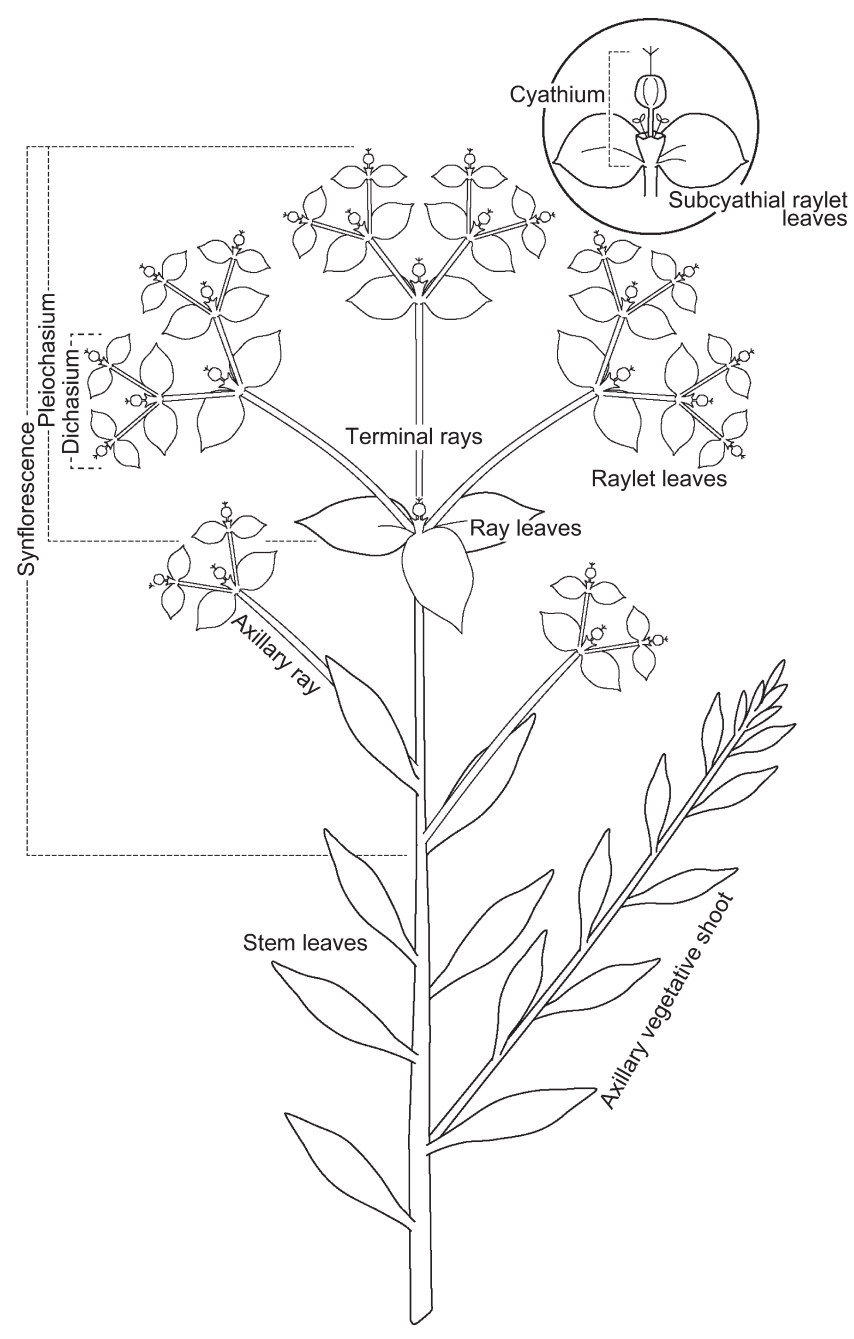


DNA extraction, amplification, and sequencing. - Genomic DNA was obtained from silica-gel-dried leaf material as well as from leaf fragments from herbarium specimens. For total DNA isolation and amplification of the nrITS region, we followed the protocols described in Kryukov \& al. (2010), Barres \& al. (2011), Frajman \& Schönswetter (2011), and Yang $\&$ Berry (2011). The chloroplast $n d h F$ gene was amplified as two overlapping fragments using primers 536f and 1318r (Olmstead \& Sweere, 1994) for the $5^{\prime}$ region, and primers $1000 \mathrm{f}$ (TAGGTATGGGGTCTTWTCG) designed in the Berry lab and 2110ri (Steinmann \& Porter, 2002) for the $3^{\prime}$ region. The PCR reaction mix contained $0.15 \mu \mathrm{L}$ of 5 units/ $\mu \mathrm{L}$ Ex Taq (Takara Bio Inc., Otsu, Shiga, Japan), $2.5 \mu \mathrm{L}$ 10× Ex Taq Buffer, $2.0 \mu \mathrm{L}$ dNTP $(2.5 \mathrm{mM}), 1.0 \mu \mathrm{L}$ of each primer $(10 \mu \mathrm{M})$, 1.0-2.0 $\mu \mathrm{L}$ of diluted template DNA (dilution varied between $1 / 25$ to $1 / 50$ ), and $\mathrm{ddH}_{2} 0$ to bring the final volume to $25 \mu \mathrm{L}$. The PCR amplification consisted of an initial 4 min denaturing step at $95^{\circ} \mathrm{C}$ followed by 40 cycles of $45 \mathrm{~s}$ denaturing at $95^{\circ} \mathrm{C}, 45 \mathrm{~s}$ annealing at $53.6^{\circ} \mathrm{C}$, and $2 \mathrm{~min}$ "slow and cold" extension at $65^{\circ} \mathrm{C}$ (Shaw \& al., 2007). The PCR products were purified using ExoSap-IT (USB Corporation, Cleveland, Ohio, U.S.A.) or the QIAquick PCR Purification Kit (Qiagen, Valencia, California, U.S.A.). The purified PCR products were sequenced using BigDye chemistry (Applied Biosystems Incorporated, Foster City, California, U.S.A.) on an AB 3730xl capillary sequencer at the University of Michigan DNA Sequencing Core.

Data assembly and phylogenetic analyses. - Chromatogram files were assembled and edited with Sequencher v.4.10.1 (Gene Codes, Ann Arbor, Michigan, U.S.A.). Initial sequence alignments were performed with MAFFT v.5. (Katho \& al., 2005) using the default parameters, and the final alignments were adjusted manually in MacClade v.4.08 (Maddison \& Maddison, 2005) using a similarity criterion (following recommendations in Simmons, 2004). The number of parsimonyinformative sites was estimated in PAUP* (Swofford, 2003).

RAxML v.7.0.3 (Stamatakis, 2006) was used to conduct maximum likelihood (ML) phylogenetic analyses on the ITS, $n d h F$, and combined ITS $+n d h F$ datasets, with gaps treated as missing data. As recommended by the RAxML manual, the nucleotide substitution model was set to GTR $+\gamma$. We performed 500 ML bootstrap (BS) replicates, followed by a thorough ML search for the best tree. The resulting ITS and $n d h F$ trees were visually inspected to check for congruence and to identify problematic sequences. There were two main areas of incongruence between the ITS and $n d h F$ phylogenies. One involved a group including E. lagascae, E. lathyris, and E. phymatosperma and the other involved E. szovitsii (see Results). The incongruences were not highly supported in either of the individual analyses, so the sequences were retained in the concatenated dataset. For the combined ML analyses, we partitioned the dataset between the ITS and $n d h F$ regions.

For Bayesian (BI) analysis of the combined dataset, we used MrBayes v.3.1.2 (Huelsenbeck \& Ronquist, 2001; Ronquist \& Huelsenbeck, 2003), partitioning the dataset between the ITS and $n d h F$ regions. The ITS region was not further partitioned. The nucleotide substitution model GTR $+\mathrm{I}+\gamma$ was applied to both partitions, as selected by AIC in jModelTest v.0.1.1
(Posada, 2008). Three independent runs of four chains each (three heated, one cold) were run for 21.5 million generations, starting from random trees, using the default temperature of 0.2 , and sampling trees every 1000 generations. The resultant Ln likelihood and model parameters from the three independent runs were visually inspected with Tracer v.1.5 (Rambaut \& Drummond, 2007) to verify run convergence and stationarity as indicated by ESS values. Trees sampled from the first 3.4 million generations (16\%) were discarded as burn-in, using the remaining trees from all three runs to compute the majorityrule consensus tree.

Sectional and subsectional delimitation. - The primary taxonomic groupings we recognized within E. subg. Esula are at the level of section, but we further divided two sections into well-defined subsections. In most cases we use the criterion of monophyly to define these subdivisions of a genus (sections, subsections). In the few instances where nrITS and $n d h F$ provided conflicting phylogenetic signal, we used morphological and biogeographical considerations to reach a consensus view (similar to the evolutionary classification model proposed by Hörandl \& Emadzade, 2012). These cases are further treated in the Discussion and Taxonomic Treatment sections.

\section{RESULTS}

Our expanded sampling of E. subg. Esula covered approximately $60 \%$ of the species in the subgenus (Table 1; Electr. Suppl: Appendix S1). Ingroup sampling included 264 species (619 accessions) for the nuclear ribosomal ITS and 189 species (293 accessions) for the chloroplast $n d h F$ region, for a total of 273 species of $E$. subg. Esula sampled. Of the sequences used in the analyses, 270 ITS and $253 n d h F$ sequences were newly

Table 1. Summary statistics from ITS, $n d h F$, and combined ITS $+n d h F$ datasets for Euphorbia subg. Esula and outgroup species analyzed in this study. Likelihood scores for the maximum likelihood trees from RAxML are provided (see Electr. Suppl.: Figs. S1-S3).

\begin{tabular}{llll}
\hline & ITS & $n d h F$ & $\begin{array}{l}\text { Combined } \\
\text { ITS }+n d h F\end{array}$ \\
\hline Total no. of accessions & 638 & 312 & 311 \\
Ingroup species (taxa) & $264(273)$ & $189(195)$ & $273(283)$ \\
Outgroup species & 19 & 19 & 19 \\
Unaligned length [bp] & $573-689$ & $775-1501$ & $585-2166$ \\
Aligned length [bp] & 766 & 1656 & 2422 \\
Variable characters (\%) & $510(66.6)$ & $586(35.4)$ & $1096(45.3)$ \\
Missing data [\%] & 19.95 & 11.74 & 31.52 \\
Parsimony-informative sites & & & \\
$\quad$ E. subg. Esula & 372 & 311 & 683 \\
$\quad$ E. subg. Esula + outgroup & 411 & 392 & 803 \\
ML score [lnL] & -26615.94 & -12308.45 & -35268.64 \\
\hline
\end{tabular}


generated and represent for many species their first inclusion in a phylogenetic analysis. Gaps in the sampling were minor and corresponded mostly to rare or poorly collected species.

As a result of this comprehensive sampling, the main clades of E. subg. Esula identified by Barres \& al. (2011), Frajman \& Schönswetter (2011) and Horn \& al. (2012) were all significantly expanded in the present study. An example of this is E. sect. Holophyllum, which was previously represented solely by E. isatidifolia in Barres \& al. (2011). Here the section is represented by a clade of 13 species. Our additional sampling allowed us to recognize 21 sections in E. subg. Esula (vs. 11 in Frajman \& Schönswetter, 2011), four of which are newly described and two of which are elevated to sectional rank (see Taxonomic Treatment; Figs. 4, 5; Electr. Suppl.: Figs. S1-S3).

Individual and combined datasets. - Summary statistics for the molecular markers sequenced in this study are provided in Table 1 . The ITS dataset contained a relatively high proportion of variable sites compared to $n d h F(66.6 \%$ vs. $35.4 \%)$. The $n d h F$ coding region was unambiguously aligned, with relatively fewer variable sites compared to ITS. Results of the individual ITS and $n d h F$ ML phylogenetic analyses (with full accession sampling) are shown in the Electronic Supplement (Figs. S1, $\mathrm{S} 2)$. The monophyly of $E$. subg. Esula is strongly supported by ML analysis of the ITS dataset (BS $=90 \%$; Electr. Suppl.: Fig. S1) and weakly supported by ML analysis of the $n d h F$ data (BS $=63 \%$; Electr. Suppl.: Fig. S2). The majority of sections circumscribed from the analyses of the combined ITS $+n d h F$ dataset (see below) were also strongly to moderately supported as monophyletic in both the ITS tree (BS $\geq 90 \%$ for 18 of 21 sections; Electr. Suppl.: Fig. S1) and the $n d h F$ tree (BS $\geq 72 \%$ for 18 of 21 sections; Electr. Suppl.: Fig. S2).

$\mathrm{ML}$ and BI results for the combined dataset are congruent for most moderately or highly supported nodes ( $\mathrm{BS} \geq 50$ and $\mathrm{PP}$ $\geq 0.80$ ) and produced a well-resolved phylogeny overall (Figs. 4, 5; Electr. Suppl.: Fig. S3). Euphorbia subg. Esula is strongly supported as monophyletic in both the ML and BI analyses of the combined dataset $(\mathrm{PP}=1.00 ; \mathrm{BS}=96 \%)$. All sections are labeled consistently across Figures 4 and 5 and Figures S1 to S3 (Electr. Suppl.).

Phylogenetic structure. - The backbone structure of $E$. subg. Esula, as depicted in the combined ITS $+n d h F$ analyses (Figs. 4, 5; Electr. Suppl.: Fig. S3), agrees with the overall phylogenetic structure of $E$. subg. Esula recovered in Horn \& al. (2012). Six of the 21 sections represented here (E. sect. Lagascae, sect. Holophyllum, sect. Szovitsiae, sect. Herpetorrhizae, sect. Biumbellatae, sect. Arvales), however, were missing from Horn \& al. (2012). Of these, E. sect. Lagascae and sect. Holophyllum represent important additions to the backbone structure of E. subg. Esula.

The monophyly of all circumscribed sections is strongly to moderately supported in the combined ITS $+n d h F$ analysis ( $\mathrm{PP} \geq 0.92$ and/or BS $\geq 84 \%$; Figs. 4, 5; Electr. Suppl.: Fig. S3), with the exception of $E$. sect. Exiguae. Our combined analysis recovered $E$. sect. Lathyris as the earliest diverging lineage in the subgenus, followed by E. sect. Lagascae. The remainder of the subgenus can be divided into two major clades: the first contains E. sect. Holophyllum and sect. Helioscopia, whereas the

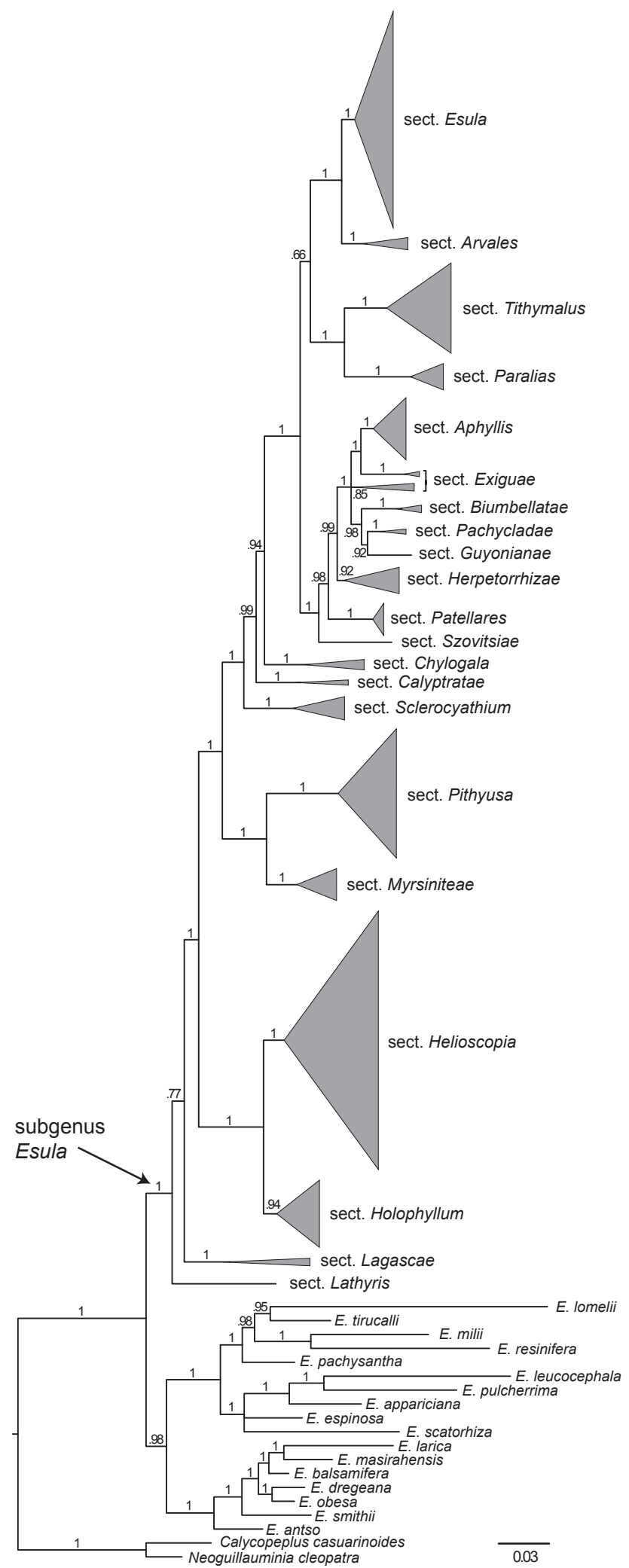

Fig. 4. Schematic representation of the Bayesian phylogram from analysis of the combined ITS $+n d h F$ dataset of Euphorbia subg. Esula and outgroups. Sections recognized in our classification are represented by filled triangles whose vertical axes are scaled to reflect the number of species in each section. Bayesian posterior probabilities $(\geq 0.66)$ are indicated above the branches. 


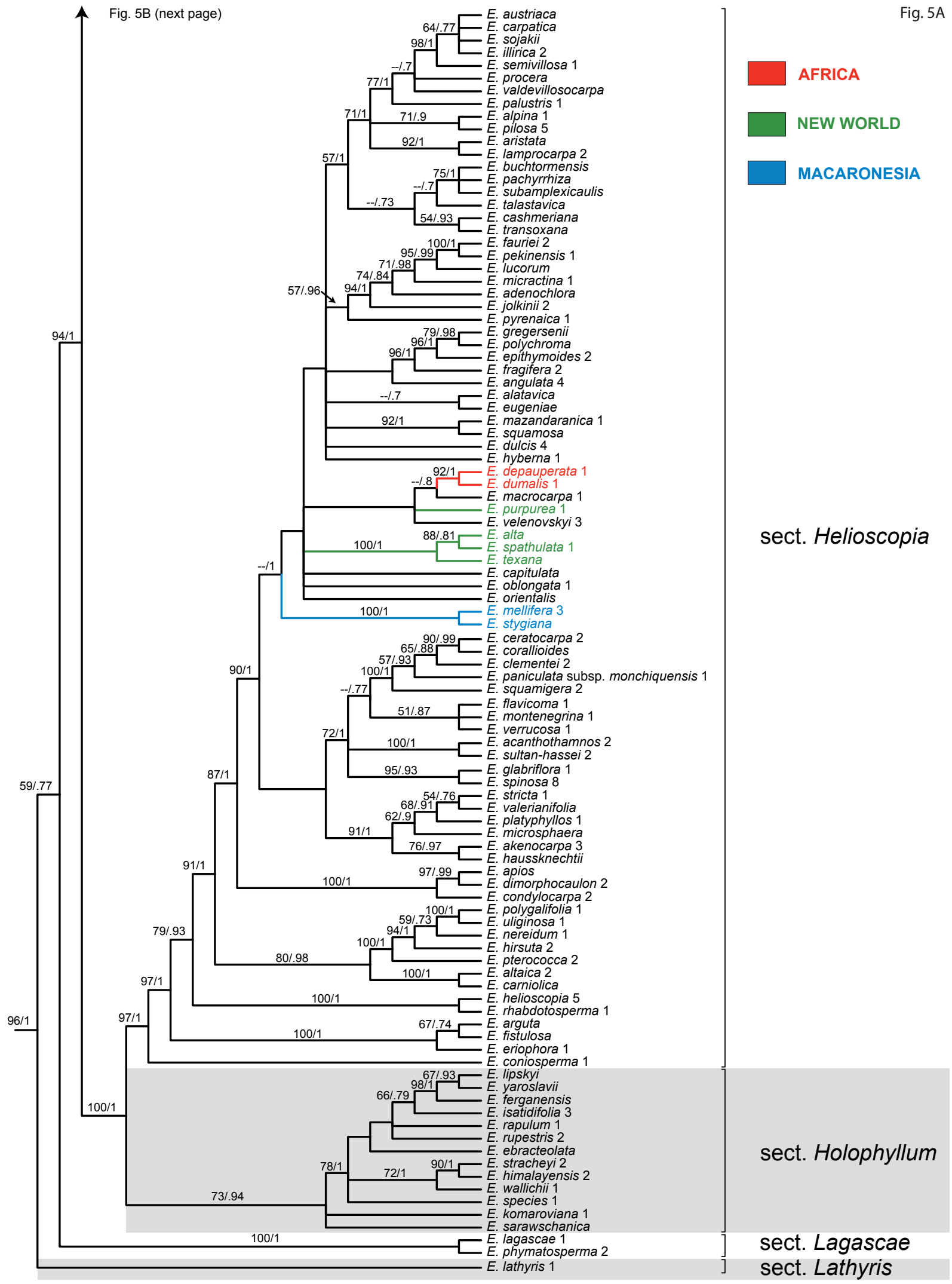

Fig. 5A-D. Fifty percent majority-rule consensus cladogram from Bayesian analysis of the combined ITS + ndhF dataset of Euphorbia subg. Esula (outgroups have been pruned from the figure; see Fig. 4). Maximum likelihood bootstrap values ( $\geq 50 \%)$ and Bayesian posterior probabilities $(\geq 0.70)$ and are indicated above the branches, separated by a slash mark. Sections are indicated to the right. Species distributed outside of Eurasia are in color. 
second, more diverse clade contains the remaining 17 sections (E. sect. Myrsiniteae to sect. Esula). The Myrsiniteae-Esula clade can itself be divided into two parts: one consisting of E. sect. Myrsiniteae and sect. Pithyusa, and the other consisting of a grade beginning with E. sect. Sclerocyathium, sect. Calyptratae, and sect. Chylogala, followed by the SzovitsiaeEsula clade. The latter contains twelve sections distributed into two main clades: the Szovitsiae-Aphyllis clade (E. sect. Szovitsiae, sect. Patellares, sect. Herpetorrhizae, sect. Exiguae, sect. Guyonianae, sect. Pachycladae, sect. Biumbellatae, sect. Aphyllis) and the Paralias-Esula clade (E. sect. Paralias, sect. Tithymalus, sect. Arvales, sect. Esula).

Relationships among species in many small and mediumsized sections are usually well-resolved (e.g., in E. sect. Arvales and sect. Tithymalus), as are most relationships within $E$. sect. Pithuysa, a relatively diverse clade of 51 species. However, within three of the most species-rich sections of E. subg. Esula (E. sect. Aphyllis, sect. Esula, sect. Helioscopia), there is little resolution between many of the species, although there is good support for certain groups of species, such as the pencilstemmed group of E. sect. Aphyllis subsect. Africanae and the two African-centered groups within E. sect. Esula (Fig. 5).

For E. subg. Esula, analysis of the ITS dataset yielded a phylogenetic hypothesis (Electr. Suppl.: Fig. S1) that was largely congruent with the topology of the $n d h F$ tree (Electr. Suppl.: Fig. S2). There are two main instances of topological incongruence between the ITS and $n d h F$ datasets, but in neither instance is the incongruence strongly supported. The first involves the positions of E. sect. Lathyris and sect. Lagascae. In the ITS phylogeny (Electr. Suppl.: Fig. S1), E. lathyris is placed sister to E. sect. Pithyusa (BS $<50 \%$ ), and E. sect. Lagascae is recovered as sister to $E$. sect. Myrsiniteae (BS $=56 \%$ ). In the $n d h F$ tree (Electr. Suppl.: Fig. S2), these two sections form a basal grade ( $\mathrm{BS}=56 \%$ ), just as they also do in the analyses of the combined ITS $+n d h F$ dataset $(\mathrm{BS}=59 \%$ and $\mathrm{PP}=0.77$; Figs. 4, 5; Electr. Suppl.: Fig. S3). The second incongruence involves $E$. sect. Szovitsiae, which includes the single species E. szovitsii. In the ITS phylogeny, E. szovitsii is sister to E. sect. Arvales + sect. Esula (BS $=75 \%$; Electr. Suppl.: Fig. S1), while in the $n d h F$ tree it is sister to part of $E$. sect. Herpetorrhizae (BS $=63 \%$; Electr. Suppl.: Fig. S2). In the combined ITS $+n d h F$ tree, E. szovitsii is recovered as sister to the Patellares-Aphyllis clade $(\mathrm{BS}=92 \%$ and $\mathrm{PP}=1.0$; Figs. 4, 5; Electr. Suppl.: Fig. S3).

Other areas of minor incongruence are almost entirely restricted to parts of the Szovitsiae-Aphyllis clade, where E. sect. Exiguae, sect. Guyonianae, and sect. Herpetorrhizae show minor differences in placements between the datasets. Backbone relationships in this area of the phylogeny, however, are generally poorly resolved, and a number of nodes have low support (Fig. 5; Electr. Suppl.: Figs. S1-S3). This part of the phylogeny also contains the only section in $E$. subg. Esula (E. sect. Exiguae) that is not recovered as monophyletic in the combined ITS $+n d h F$ analysis. In the ITS phylogeny, $E$. sect. Exiguae is monophyletic, but poorly supported as part of a

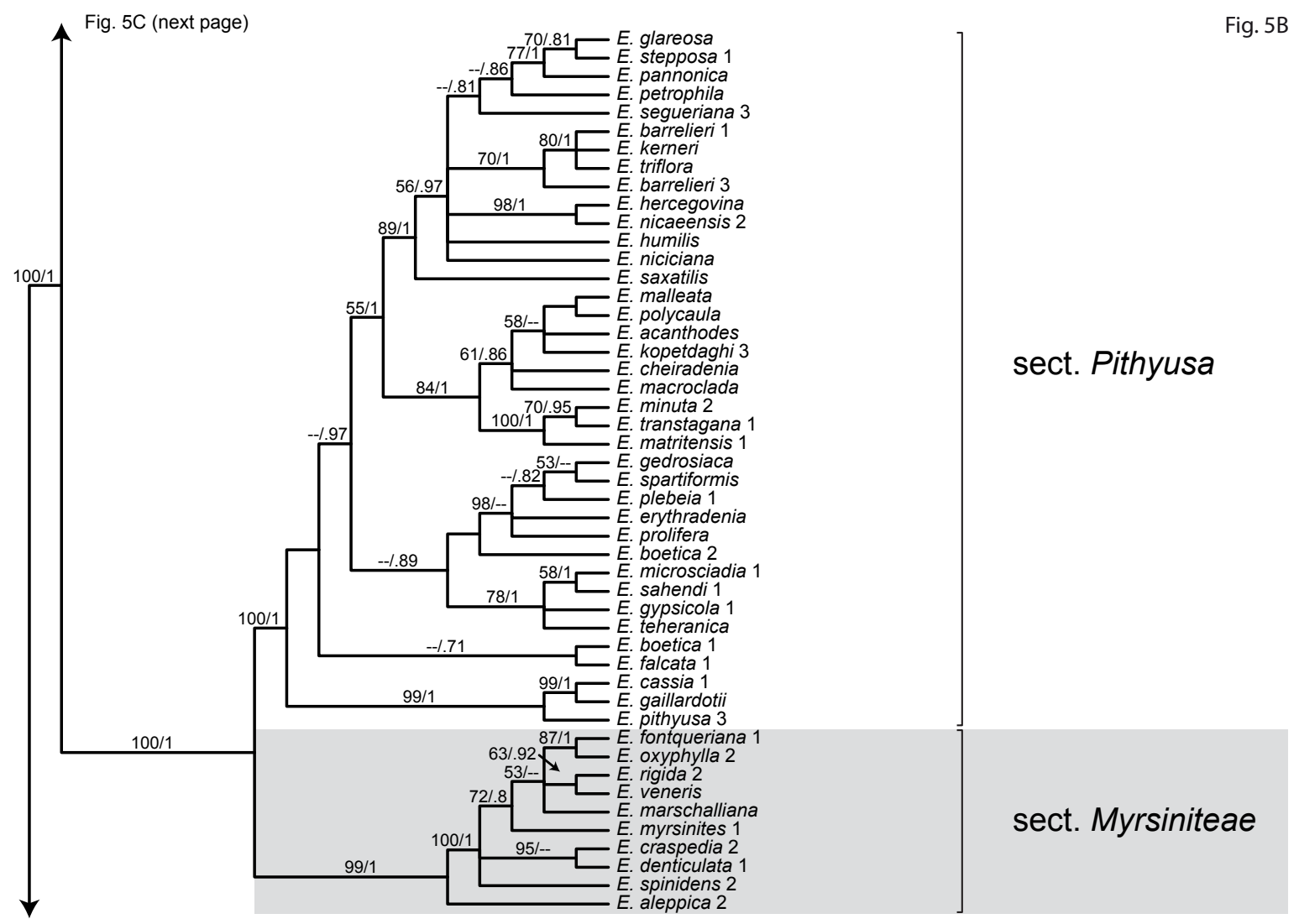

Fig. 5A (previous page) 
larger clade that includes E. sect. Guyonianae, sect. Biumbellatae, and sect. Pachycladae (BS = 36\%; Electr. Suppl.: Fig. S1). In the $n d h F$ phylogeny (Electr. Suppl.: Fig. S2), E. sect. Exiguae forms two separate subclades: one subclade (E. $d r a-$ cunculoides, E. rimarum) is sister to E. sect. Aphyllis, while E. exigua is part of a broader polytomy (E. medicaginea is not represented in the $n d h F$ tree). Analyses of the combined dataset (Figs. 4, 5; Electr. Suppl.: Fig. S3) provide a similar structure to the $n d h F$ phylogeny, with the clade of E. dracunculoides and E. rimarum sister to $E$. sect. Aphyllis and the clade of E. exigua and $E$. medicaginea as part of a broader polytomy.

\section{DISCUSSION}

Our molecular results confirm the monophyly of $E$. subg. Esula and its sister relationship to the other three subgenera of Euphorbia, in agreement with Horn \& al. (2012). More importantly, they reveal a well-resolved phylogeny within E. subg. Esula (Figs. 4, 5) that now allows us to recognize 21 sections (seven of them newly recognized here), vs. only 11 sections recognized in the latest study of the subgenus by Frajman \& Schönswetter (2011). The results of our broader sampling more clearly demonstrate that the region extending from central Eurasia to the Mediterranean is the center of diversity for the subgenus, in terms of both the number of species $(n=$ $302)$ and the number of different sections $(n=21)$ present there. Of the 34 species in E. subg. Esula that are native to the New World, we can infer from their phylogenetic positions that there were at least four independent colonizations of the New World. Likewise, we can infer at least three separate introductions of the subgenus into tropical and southern Africa and more distant islands. Morphologically, most of the species conform to the "leafy spurge" concept, but the nearly leafless pencil-stemmed, succulent habit has evolved on two separate occasions and the dendroid habit three times. Some characters of the seeds and

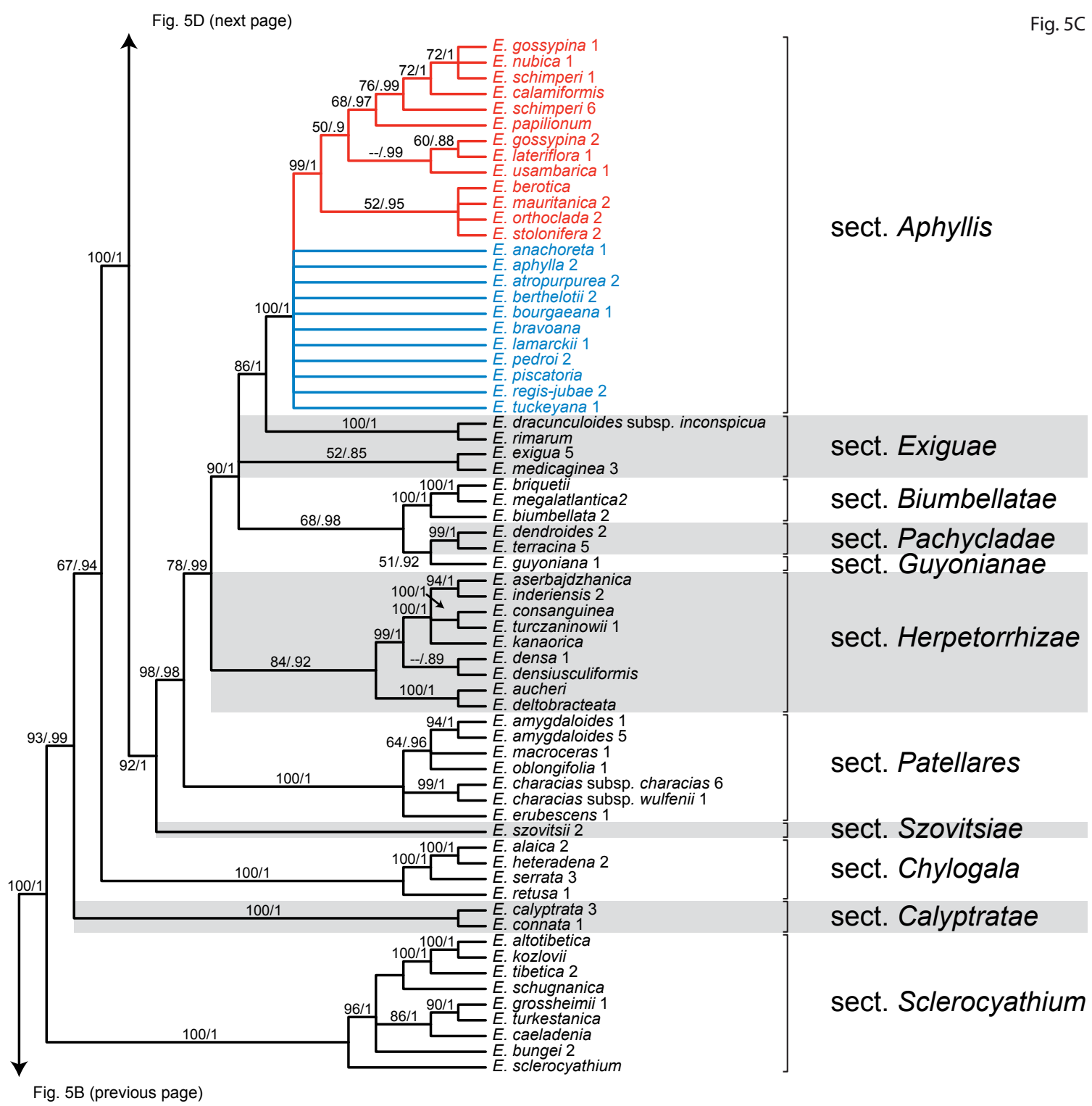


cyathial gland appendages appear to be diagnostic for particular sections, but there is enough variation and overlap to make ready distinction of all sections problematical. Below we discuss our findings for the major lineages within E. subg. Esula and summarize the biogeographical history and morphological evolution of the group. Lastly, in the Taxonomic Treatment, we present our new sectional classification of the subgenus and place close to $96 \%$ of the ca. 480 currently recognized species into one of the 21 sections.

Basal lineages. - The placement of E. lathyris as sister to the rest of the subgenus was previously supported by both Horn \& al. (2012) and by Frajman \& Schönswetter (2011). Results from our combined analyses are congruent with this topology but have low support $(\mathrm{BS}=59 \%$ and $\mathrm{PP}=0.77$; Fig. 5). The nrITS phylogeny is discordant with both the combined and chloroplast results, placing E. lathyris sister to $E$. sect. Pithyusa with low support (BS < 50\%; Electr. Suppl.: Fig. S1) in our analyses or else in an unresolved position in the nrITS analysis of Horn \& al. (2012: fig. S10). The isolated position of the monotypic $E$. sect. Lathyris is consistent with its unique morphology; E. lathyris is the only species in the subgenus with decussate stem leaves and with capsules that are spongy and indehiscent. Still, it resembles most other species in the subgenus in having exstipulate leaves, pleiochasial synflorescences,

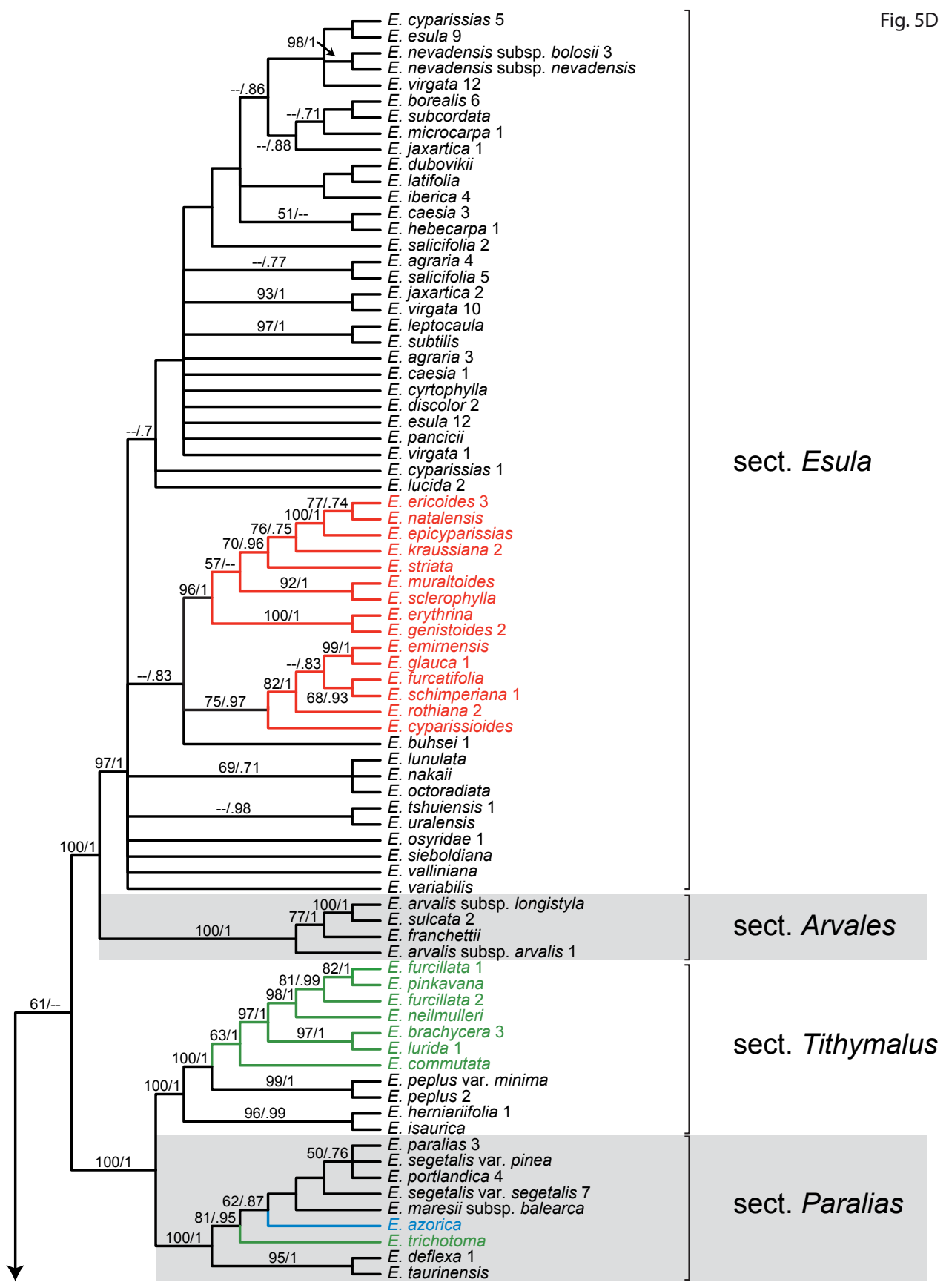

Fig. 5C (previous page) 
four cyathial glands, and carunculate seeds. Euphorbia lathyris is semi-domesticated, and its seeds have been used for oil production (Prokhanov, 1949), so it is possible that some of its characters, such as indehiscent capsules, could be related to selective breeding.

The recognition and circumscription of $E$. sect. Lagascae is novel to this study, with E. lagascae and E. phymatosperma strongly supported as sister species, but their position in the phylogeny was poorly resolved between ITS and $n d h F$, similar to the case of E. lathyris. The species in this section are annuals with linear to oblong leaves and subcyathial raylet leaves that are similar to E. lathyris, but the cyathial glands are smaller and lack the knobby appendages of that species. Additional molecular markers might increase support for its early diverging position in the subgenus, as happened with E. lathyris in Horn \& al. (2012).

The Holophyllum-Helioscopia clade. - Our study is the first to extensively sample members of $E$. sect. Holophyllum, a mainly montane Asian group with fleshy-thickened roots (Fig. 2A). Our results clearly place E. sect. Holophyllum as sister to E. sect. Helioscopia, which was previously recovered as the lone sister clade to the remainder of $E$. subg. Esula, except for E. lathyris (Frajman \& Schönswetter, 2011; Horn \& al., 2012). Both sections share rounded and unappendaged cyathial glands, smooth or rarely foveolate seeds (Fig. 2M-O), and leaves with conspicuous pinnate venation, but they generally differ in the capsule surface, which is smooth in E. sect. Holophyllum and usually verrucose or tuberculate in E. sect. Helioscopia. Euphorbia sect. Holophyllum is notable for the disjunct distribution of E. isatidifolia in the Iberian Peninsula, far from the remainder of the section in central and eastern Asia.

Euphorbia sect. Helioscopia is the largest section of the subgenus, with about 135 species that are characterized by unappendaged cyathial glands and verrucose or tuberculate fruits (Fig. 2F). However, there are several species with smooth fruits that are scattered throughout the section (e.g., E. coralloides, E. helioscopia, E. illirica, E. lamprocarpa, E. texana). Seeds in $E$. sect. Helioscopia are generally smooth or rarely rugulose or foveolate (Fig. 2N, O), dark brown or black, and a few of the species either lack a caruncle (e.g., E. eriophora) or else have a much reduced one (e.g., E. coniosperma, E. orientalis). Our phylogeny does not support previous morphology-based subdivisions in this group (e.g., Prokhanov, 1964; Baikov, 2007; Geltman, 2009), but there are several well-defined lineages that can be distinguished.

The first diverging lineage is the annual E. coniosperma, which emerges as the sister species of the rest of the section (Fig. 5). This is followed by a grade of two other groups of annual species. The first includes E. arguta, E. eriophora, and $E$. fistulosa, while the second includes the type species of the section, E. helioscopia, along with E. rhabdotosperma and possibly some other unsampled annual species (e.g., E. oxyodonta, E. peltata, E. sintenisii). The next diverging lineage in the combined tree is a Mediterranean/North African assemblage of generally hairy perennials that includes E. hirsuta, E. nereidum, E. polygalifolia, E. pterococca (the sole annual in this group), and E. uliginosa. There is also a well-supported group, previously identified as E. subsect. Apios Geltman (Geltman, 2005), that includes the mostly eastern Mediterranean tuberous perennials E. anthula, E. apios, E. condylocarpa, E. dimorphocaulon, and E. pseudoapios. Beyond those groups, however, there is little support to the remaining backbone structure of the section, although there are other well-defined groups of species, such as the Macaronesian E. mellifera and E. stygiana, and the eastern African group represented by $E$. depauperata and E. dumalis. Likewise, the annual to biennial North American E. alta, E. spathulata, and E. texana form a well-supported clade, whereas the perennial and geographically isolated E. purpurea, from the Appalachian Mountains in eastern North America, is not part of the same clade as the annual American species. Another unsampled annual species in this section, E. philippiana, is widely disjunct to central Chile and is the only native species of E. subg. Esula in South America. Based on its morphology, we expect it to belong to the E. spathulata species group.

The Myrsiniteae-Pithyusa clade. - The existence of this clade agrees with Frajman \& Schönswetter (2011) and Horn $\&$ al. (2012). It is also supported by morphological characters such as the perennial habit (though E. aleppica in $E$. sect. Myrsiniteae and two species in E. sect. Pithyusa are annuals), semisucculent and glaucous leaves, and a papillose indumentum (in most species of both sections). Our most notable finding in this clade was the position of the newly sampled E. aleppica as sister to the rest of $E$. sect. Myrsiniteae. The placement of this widespread Mediterranean species was formerly uncertain, due to its unusual, densely spiraled, linear stem leaves (Fig. 2B) (Khan, 1964). However, E. aleppica shares with the rest of E. sect. Myrsiniteae the somewhat fleshy, minutely serrulate raylet leaves, the lack of bracteoles on the male flowers, and the Mediterranean distribution. Serrulate and mucronate raylet leaves are also present in E. sect. Pithyusa (e.g., E. falcata, E. gaillardotii, E. pithyusa, E. matritensis). Euphorbia sect. Myrsiniteae is one of the most distinctive groups of $E$. subg. Esula, both morphologically and ecologically, and it was previously treated as a subsection of $E$. sect. Paralias (Boissier, 1862; Prokhanov, 1949; Pahlevani \& al., 2011). Prokhanov's system also included members of E. sect. Pithyusa within E. sect. Paralias, under the name E. subsect. Conicocarpae. These previous taxonomic placements are not supported by our results, which show clearly that E. sect. Paralias and the Myrsiniteae-Pithyusa clade are not closely related to each other (Fig. 5).

The Sclerocyathium-Chylogala grade. - A grade of three well-supported clades (E. sect. Sclerocyathium, sect. Calyptratae, sect. Chylogala) follows the Myrsiniteae-Pithyusa clade in the combined ITS $+n d h F$ phylogeny (Figs. 4, 5). Euphorbia sect. Sclerocyathium and sect. Calyptratae are newly recognized here, although they have both been represented in previous studies by one or two species (Barres \& al., 2011; Horn \& al., 2012). These three sections are small groups of species that all share sharply and irregularly serrate leaves, usually unappendaged cyathial glands, and usually large and elaborate caruncles on the seeds (Fig. 2H, I, R). In addition to these morphological similarities, they share the 
preference for extreme habitats such as sandy deserts and dry, stony, montane slopes. In the ITS phylogeny, E. sect. Chylogala and sect. Sclerocyathium form sister clades, but with low bootstrap support (BS $=60 \%$; Electr. Suppl.: Fig. S1), whereas in the $n d h F$ and combined phylogenies, they form a grade with E. sect. Calyptratae in the middle (Electr. Suppl.: Fig. S2). In E. sect. Chylogala, E. alaica, E. heteradena, and E. serrata are morphologically similar yet quite variable, particularly in the number of cyathial glands. Euphorbia retusa, which is morphologically more distinct, occupies a position sister to the remainder of the section in the individual and combined trees (Fig. 5; Electr. Suppl.: Figs. S1-S3).

The Szovitsiae-Aphyllis clade. - This clade encompasses a total of eight sections but accounts for only $13 \%$ (or 61 species) of the species diversity in $E$. subg. Esula. In many regards, this is the most complex part of the E. subg. Esula phylogeny, with a series of small, yet morphologically distinct sections, and with one instance of strong phylogenetic conflict between the individual datasets. Four of these small sections are newly described and circumscribed here.

In the combined ITS $+n d h F$ phylogeny, E. sect. Szovitsiae is recovered as the basal lineage of this clade (Figs. 4, 5; Electr. Suppl.: Fig. S3). This is the first time E. szovitsii has been sampled for a plastid region and the first time the $\mathrm{cp}$ DNA has been analyzed in combination with ITS. The basal position of E. szovitsii in the combined dataset, however, is different from the placements recovered in the analyses of the individual datasets. The ITS phylogenies of Kryukov \& al. (2010) and Salmaki \& al. (2011) placed E. szovitsii sister to $E$. sect. Esula. This placement is similar to our results, with the exception that we also sampled $E$. sect. Arvales, which is positioned between $E$. sect. Szovitsiae and E. sect. Esula in our ITS phylogeny (Electr. Suppl.: Fig. S1). In the $n d h F$ phylogeny (Electr. Suppl.: Fig. S2), E. szovitsii is sister to E. aucheri and E. deltobracteata in E. sect. Herpetorrhizae. The markedly incongruent position between the plastid and nuclear datasets suggests that E. szovitsii may be of hybrid origin. Morphologically, E. szovitsii resembles members of E. sect. Arvales, consistent with its position in the ITS phylogeny. Plants from these two sections are usually diminutive annuals, with a tiny cyathial involucre and minute glands with whitish, horn-like appendages, and they are centered geographically in central Asia and the Iranian highlands. Future studies should include additional molecular markers and cloning of nuclear markers to determine if $E$. szovitsii is indeed of hybrid origin.

Apart from the enigmatic E. szovitsii, the SzovitsiaeAphyllis clade is characterized by a basal grade formed by E. sect. Patellares followed by E. sect. Herpetorrhizae, a group that was not recognized by Frajman \& Schönswetter (2011). Euphorbia sect. Patellares is strongly supported by molecular characters (BS $=100 \%$ and $\mathrm{PP}=1$; Fig. 5) as well as by the morphological synapomorphy of connate raylet leaves (which appear to have arisen independently in $E$. connata of $E$. sect. Calyptratae and in two North American species of $E$. sect. Tithymalus). Relationships of species within E. sect. Patellares are poorly resolved, in contrast to E. sect. Herpetorrhizae, which contains two well-supported subclades that we recognize as subsections based on morphological characters, specifically the phyllotaxy of the basal stem leaves and plant stature (see Taxonomic Treatment).

The least resolved portion of the E. subg. Esula phylogeny lies between E. sect. Herpetorrhizae and E. sect. Aphyllis (Figs. 4,5 ), with a group of species of mostly western Mediterranean distribution that were previously not placed in any section. We propose four new sections to accommodate these species, namely, E. sect. Exiguae, sect. Guyonianae, sect. Pachycladae, and sect. Biumbellatae. These sections are all small groups that are each very distinct morphologically (see Taxonomic Treatment). Our molecular results do not conclusively resolve a monophyletic $E$. sect. Exiguae (there are two separate clades in the combined analysis), but the four members of the section do form a single clade in the ITS analysis, albeit with low BS support (Electr. Suppl.: Fig. S1). The section is supported by several morphological similarities among the sampled species (E. dracunculoides, E. rimarum, E. medicaginea, E. exigua), such as polymorphic leaves, ornamented seeds (Fig. 2V), smooth to finely granulate capsules, and long horn-like gland appendages.

In the final portion of this clade, E. sect. Aphyllis is strongly supported as monophyletic, but relationships among the species included in this section are not fully resolved. A better resolved phylogeny for this section, based on seven chloroplast markers, was published by Barres \& al. (2011), however, it showed several areas of topological conflict with the nuclear phylogeny based on ETS and ITS in the same study. A similar conflicting scenario is shown in our different analyses (Fig. 5; Electr. Suppl.: Figs. S1, S2).

In our combined analysis, the African, Arabian, and Madagascan species of $E$. sect. Aphyllis form a well-supported subclade, whereas the Macaronesian and Mediterranean species form a polytomy. We based our division of this section into two subsections (see Taxonomic Treatment) on the topology of our combined analysis as well as on the nuclear phylogeny of Barres $\&$ al. (2011: fig. 2A). Relationships within these subsections are poorly resolved, and disentangling them and finding the causes of topological incongruence will require further study. Barres \& al. (in prep.) are taking a population-level approach using AFLP markers to further investigate species relationships within E. subsect. Macaronesicae of E. sect. Aphyllis.

Euphorbia subsect. Macaronesicae is a morphologically and biogeographically coherent group that can be readily distinguished from $E$. subsect. Africanae. Relationships within $E$. subsect. Macaronesicae are poorly resolved, however, and the extremely short branch lengths in the phylograms suggest a fairly recent or rapid radiation on oceanic islands (Electr. Suppl.: Figs. S1-S3). In previous molecular studies, E. tuckeyana from the Cape Verde Islands was recovered as sister to the rest of E. sect. Aphyllis (Barres \& al., 2011), but we include this species in E. subsect. Macaronesicae because of its morphological affinities to other members of the subsection. Euphorbia tuckeyana is a dichotomously branching dendroid shrub with large, persistent leaves concentrated in a terminal rosette on young stems, and it has large, persistent cyathial bracts and furrowed seeds. Its isolation from the mainland and from other islands in Macaronesia may help explain its long branch in the 
combined tree (Electr. Suppl.: Fig. S3). All remaining members of the subsection are dendroid shrubs (Fig. 2D), except for E. aphylla, which is an essentially leafless pencil-stemmed, succulent shrub.

Euphorbia subsect. Africanae includes all of the pencilstemmed species (Fig. 2C) in E. subg. Esula, apart from E. aphylla. There are two well-supported subgroups in this subsection (Fig. 5). One is composed of the southern African $E$. berotica, E. mauritanica and E. stolonifera, and the Madagascan E. orthoclada. The other consists of several very similar species from central to northeastern Africa and the Arabian Peninsula. The latter subgroup includes the leafy E. usambarica, which is anomalous in this subsection in being non-succulent and possessing persistent leaves, but otherwise agrees with the members of the group in its central unisexual cyathium.

The Paralias-Esula clade. - This group includes four sections: Paralias, Tithymalus, and Esula that were recognized by Frajman \& Schönswetter (2011) and the newly recognized $E$. sect. Arvales. In both the individual and combined trees, E. sect. Paralias and sect. Tithymalus are well-supported as sister clades (Figs. 4, 5; Electr. Suppl.: Figs. S1-S3). Many species in both sections share characters such as a reticulatefoveolate seed surface and long-horned cyathial glands (Fig. 2K). Euphorbia sect. Paralias also shares the foveolate seed surface and acute, whitish cyathial appendages with $E$. sect. Herpetorrhizae. Several of the species in E. sect. Paralias are restricted to coastal dunes and beaches, and the Mediterranean E. paralias and the Caribbean E. trichotoma share a similar phenotype, with tightly imbricate, isolateral leaves. Species such as E. segetalis, E. ledebourii, and E. taurinensis occur farther inland and at higher elevations and can be weedy or alien in some regions. Euphorbia sect. Tithymalus is the only section in the subgenus to have more species in the New World than in the Old World. The topology of the combined ITS $+n d h F$ phylogeny (Fig. 5; Electr. Suppl.: Fig. S3) suggests that there was a single origin of the New World species from Old World ancestors.

The small E. sect. Arvales (7 spp.) is a newly recognized section that is sister to the much more species-rich $E$. sect. Esula (96 spp.). It differs from that section in being composed of small annual herbs with more ornamented seeds. Euphorbia sect. Esula is the second-largest section of the subgenus and is most diverse in temperate Eurasia, with the majority of species occurring in steppe and forest vegetation zones. This section has given rise to the most pernicious weeds in the genus, notably E. virgata, a species native to Europe and western Asia that has extensively invaded similar steppe-like habitats in northern North America. Our results are similar to those of Frajman \& Schönswetter (2011) and indicate generally that ITS and $n d h F$ provide too little resolution to distinguish Northern Hemisphere temperate species of E. sect. Esula from one another. This pattern of low resolution is reinforced in our individual and combined analyses (Fig. 5; Electr. Suppl.: Figs. S1-S3), where we included a total of 14 different accessions of $E$. virgata that appear scattered throughout the northern temperate species of E. sect. Esula. Considerable uncertainty in species delimitation among the Eurasian species of this group also complicates investigations of its evolution. The relatively poor resolution from the ITS and $n d h F$ regions could be the result of a fairly recent diversification of this group, and additional studies using more refined molecular techniques, as well as a combination of morphological, ecological, and cytological approaches, will be required to better distinguish individual taxa.

Within E. sect. Esula, there are two well-supported clades of species that lie outside the main Eurasian center of distribution. A group of ericoid-leaved herbs and broader-leaved shrublets found mostly in South Africa and adjacent montane regions of Zimbabwe and Mozambique form a distinct, strongly supported clade (E. genistoides to E. ericoides), and a largerleaved group of species from eastern, mostly montane Africa, India, Madagascar, and New Zealand (E. cyparissioides to E. emirnensis) form a second, more widely distributed, less strongly supported clade (Fig. 5; Electr. Suppl.: Fig. S3). It is possible that other far-flung species such as E. borbonensis (Réunion) and E. reineckii (Samoa) that have not been sampled yet will prove to belong to the latter group.

Biogeography. - From a biogeographic perspective, our results confirm that central Eurasia and the Mediterranean region are the centers of diversity for the subgenus, with all sections and approximately two thirds of the species present there. Species-wise, the subgenus is highly concentrated in the western Mediterranean and Irano-Turanian regions, where Turkey has 87 species, Iran 75 species, and the Caucasus area 68 species. All species occurring outside of Eurasia and the Mediterranean region are well-embedded in sections whose earliest diverging members are from that area.

In the New World, our phylogeny indicates that the 34 currently recognized native species of $E$. subg. Esula resulted from four independent introductions from the Old World (most likely from Europe and the Mediterranean region). One took place in the largely Atlantic maritime E. sect. Paralias, represented in the Caribbean by E. trichotoma. Within the large $E$. sect. Helioscopia, there were likely two separate introductions to the New World. While this is not statistically supported by our data, it is supported in the combined analysis of Horn \& al. (2012). The first involving the Appalachian perennial E. purpurea, and the second involving the annual/biennial E. alta, E. spathulata, and E. texana, and presumably the unsampled E. philippiana as well. Of the latter group, E. spathulata is widespread across North America and into Central America, while the other members of this species group are much more restricted in distribution. The diminutive E. philippiana is widely disjunct to central Chile and is the only species in E. subg. Esula native to South America. A separate New World introduction involved members of E. sect. Tithymalus. All 28 New World species in E. sect. Tithymalus appear to be derived from a single introduction, despite the fact that the group is widespread from North America into Central America and even on Hispaniola in the West Indies. The New World species of $E$. sect. Tithymalus form a clade that is sister to a grade of Old World species, including the widespread and weedy E. peplus. This pattern of multiple introductions of E. subg. Esula in the 
New World contrasts sharply with the two other subgenera of Euphorbia that also occur there, and which are far more diverse. In E. subg. Chamaesyce, Yang \& al. (2012) hypothesized one or possibly two introductions to the New World for the approximately 350 species that occur there today. Likewise, Dorsey \& al. (2013) determined that the 86 New World species in E. subg. Euphorbia form a monophyletic group, consistent with a single origin from the Old World.

The islands of Macaronesia off the Atlantic coasts of Africa and Europe harbor 13 endemic species from three different sections in E. subg. Esula, including E. sect. Helioscopia (E. mellifera, E. stygiana), E. sect. Aphyllis (all but one species of subsect. Macaronesicae), and E. sect. Paralias (E. azorica). These islands are volcanic in origin and range in age from 20.6 Ma for Lanzarote to 1.77 Ma for El Hierro, and there are numerous examples of plant taxa that have diversified there following either single or multiple colonization events (reviewed in Barres \& al., 2011). The presence on these islands of more wide-ranging leafy spurges from other sections, as well as species from the other subgenera of Euphorbia (e.g., E. balsamifera Aiton in E. subg. Athymalus and the endemic E. canariensis L. and E. handiensis Burchard in E. subg. Euphorbia) indicates that there have been numerous opportunities in Euphorbia for repeated colonizations of the islands by mainland African and European ancestors.

Outside of the Mediterranean region of northern Africa, there appear to have been three or possibly four separate introductions of the subgenus into tropical and southern Africa, one of these occurring in E. sect. Aphyllis (E. subsect. Africanae), one in E. sect. Helioscopia (e.g., E. depauperata, E. dumalis), and one or possibly two in E. sect. Esula (e.g., the E. genistoides and E. schimperiana clades). Euphorbia subsect. Africanae includes species from southern and eastern Africa, Madagascar, and the Arabian Peninsula, and this clade includes all but one of the leafless pencil-stemmed succulent species in the subgenus. They are all sister to the largely Macaronesian E. subsect. Macaronesicae in the $n d h F$ analysis (Electr. Suppl.: Fig. S2) and in the multi-locus plastid phylogeny of Barres \& al. (2011). Euphorbia sect. Aphyllis represents one of the prime examples of the "Rand Flora" disjunct distribution pattern between Macaronesia, Horn of Africa and southern Arabia, and eastern and southern Africa (Sanmartín \& al., 2010). In $E$. sect. Helioscopia, there is a small clade of montane eastern African species represented in our phylogeny by E. depauperata and $E$. dumalis. This clade is part of a larger, poorly resolved region of the $E$. sect. Helioscopia phylogeny that also includes the two Macaronesian species and the two groups of North American species mentioned above. In E. sect. Esula, one morphologically distinctive clade of around ten species of mostly ericoid-leaved herbs and shrubs has differentiated in South Africa (E. genistoides to E. ericoides in Fig. 5). It occurs in the mesic parts of the winter-rainfall Cape floristic region, in the summer-rainfall grasslands and forest margins of Natal, and extending into Zimbabwe and Mozambique. The other group in E. sect. Esula with African members is much more widespread geographically. It includes broadly distributed African species such as E. cyparissoides, but also extends into the Arabian Peninsula (E. schimperiana), Madagascar (E. emirnensis), and New Zealand (E. glauca). A final species sampled from this group is $E$. rothiana, which occurs in southern India, Sri Lanka, and southern China. Most of these widespread species in E. sect. Esula occur in inland, often montane habitats. The exception is E. glauca, which inhabits coastal sand dunes in New Zealand. Because of its habitat and its vegetative resemblance to members of $E$. sect. Paralias, we initially hypothesized that $E$. glauca belonged to that group, but our molecular results instead placed it within E. sect. Esula.

Morphological evolution. - Compared with the other subgenera of Euphorbia, E. subg. Esula is more uniform in terms of growth form, with most species being leafy, annual or perennial herbs (Fig. 2A, B) and with succulence being rare. The exceptions include the 26 species of dendroid shrubs and leafless pencil-stemmed succulents (Fig. 2C, D). Ancestral state reconstructions by Frajman \& Schönswetter (2011) and Horn \& al. (2012) showed that the herbaceous growth form was the ancestral state for the subgenus. Our results confirm that pencil-stemmed succulents and dendroid shrubs occupy derived positions within their respective clades and have arisen several times in E. subg. Esula. Pencil-stemmed succulents (Fig. 2C) are restricted to E. sect. Aphyllis, but the pencil-like, nearly leafless habit appears to have evolved twice within the section, once in the Macaronesian E. aphylla, and once in the African mainland species of $E$. subsect. Africanae, as was found by Barres \& al. (2011). Dendroid shrubs (Fig. 2D) arose independently in $E$. sect. Pachycladae (E. dendroides), E. sect. Aphyllis (many species), and at least twice in E. sect. Helioscopia (E. mellifera and E. stygiana; E. sultan-hassei). Because of its similar growth form, $E$. dendroides was previously placed along with the other dendroid members of $E$. sect. Aphyllis and E. sect. Helioscopia in the former E. subsect. Pachycladae Boiss. (Molero \& al., 2002).

In their molecular analysis of the mostly European species of $E$. subg. Esula, Frajman \& Schönswetter (2011) focused mainly on the relationships between annual and perennial species, since earlier classifications relied heavily on this distinction. Using ancestral state reconstructions, they detected nine shifts from perennial to annual herbs in five different sections of E. subg. Esula, although it remained ambiguous whether the ancestral state for the subgenus as a whole was annual or perennial. Our results generally confirm this pattern, but we have included many more annual species in our sampling, and our phylogenetic results show an even more complex pattern between annuals and perennials in the subgenus. Within the large $E$. sect. Helioscopia, the three earliest diverging lineages from E. coniosperma to E. helioscopia are all annuals (Fig. 5). Furthermore, there are at least two additional groups of annual species that are embedded among the perennial species that comprise the rest of the clade (E. haussknechtii to E. stricta; and E. texana to E. spathulata). Euphorbia sect. Tithymalus shows a similarly complex pattern to that observed in E. sect. Helioscopia. The earliest diverging Mediterranean lineage is perennial, followed by the Old World annual E. peplus. Within the remaining North American species, the annual 
E. commutata is sister to a larger clade of perennial species (Fig. 5). Euphorbia sect. Myrsiniteae was previously circumscribed as being entirely perennial, but our sampling now places the annual E. aleppica as sister to the perennial species in that section. Some of our newly recognized sections, such as E. sect. Calyptratae and sect. Sclerocyathium, have been characterized as mainly perennial but occasionally annual, so even the distinction between annuals and perennials is sometimes unclear. At a taxonomic level, the distinction between annuals and perennials can nonetheless be diagnostic for certain sections. The 14 species in E. sect. Patellares, the 23 species in E. sect. Aphyllis, the 26 species in E. sect. Holophyllum, and the nearly 100 species in $E$. sect. Esula are all perennials, whereas the seven species of the newly recognized $E$. sect. Arvales, the three species in E. sect. Lagascae, and the monotypic $E$. sect. Lathyris and sect. Szovitsiae are all annuals.

The leafy pleiochasial synflorescence (Fig. 3) is characteristic of almost all members of E. subg. Esula, but similarly developed synflorescences are also present in some lineages of the other three subgenera of Euphorbia, such as E. sect. Nummulariopsis in E. subg. Euphorbia (Dorsey \& al., 2013) and E. sect. Alectoroctonum in E. subg. Chamaesyce (Yang \& al., 2012). Often, however, the synflorescences in these other groups are simpler in structure and vary from short, dichasial cymes to simple umbel-like synflorescences (Yang \& al., 2012; Dorsey \& al., 2013). Another major difference shown by Horn $\&$ al. (2012) is that nearly all members of E. subg. Esula have retained terminal inflorescences, which is the ancestral state for the genus, whereas transitions to lateral inflorescences have occurred independently in parts of the three other subgenera of Euphorbia.

A variety of additional morphological characters has been used by botanists to differentiate taxonomic groups within E. subg. Esula, primarily the kind and number of cyathial gland appendages, indumentum, phyllotaxy, capsule surface ornamentation, leaf venation, and seed surface texture (Frajman \& Schönswetter, 2011; Horn \& al., 2012). The fact that most of these characters are homoplastic within the subgenus constrains their use as easily diagnostic characters in a sectional key, with the result that certain sections need to be keyed out two or three times (see Key to sections below). Seed caruncles (Fig. 2M-X) are fairly ubiquitous throughout the subgenus but they vary considerably in shape and size (Pahlevani \& Akhani, 2011; Salmaki \& al., 2011). Euphorbia sect. Calyptratae, sect. Chylogala, and some members of E. sect. Sclerocyathium have large and very elaborate caruncles (Fig. 2R), but caruncles have also been lost entirely in species from at least five different sections (E. sect. Esula, sect. Exiguae, sect. Guyonianae, sect. Helioscopia, and sect. Herpetorrhizae). Nonetheless, most groups can be fairly readily diagnosed by a combination of character states, and certain groups have distinctive synapomorphies or autapomorphies, such as the ebracteolate male flowers in the cyathia of $E$. sect. Myrsiniteae, the oddly spongy-lacerate and ecarunculate seeds in E. sect. Guyonianae (Fig. 2T), or the decussate stem leaves and indehiscent fruits in E. sect. Lathyris. These characteristics are all covered in the Taxonomic Treatment that follows.

\section{- TAXONOMIC TREATMENT}

This section presents a revised taxonomic treatment of E. subg. Esula based principally on the results of our molecular phylogenetic analyses. For each section we provide information on types, synonymy, a brief description, a list of included species, geographical distribution, and pertinent discussion. Those species sampled for our phylogenetic analyses and in previous studies are listed in bold italics, whereas others that are inferred to belong to a particular section by morphological or other criteria are listed in italics only. Names below species rank have been omitted from the lists below, but a complete database of names and synonyms is available online (Riina \& Berry, 2012b). References for the chromosome information provided below are available in the database under individual species records with published chromosome counts. There are still several species that clearly belong to E. subg. Esula, but which we have not yet been able to place to section, either through lack of specimens or inadequate descriptions. They are included in the database as members of E. subg. Esula and will be updated as we are able to determine their sectional status. There are also a number of new species that are in the process of being described. In this paper, there is a total of 457 species that are recognized in the 21 sections below.

Euphorbia subg. Esula Pers., Syn. Pl. 2: $14.1806 \equiv$ Esula (Pers.) Haw., Syn. Pl. Succ.: 153. $1812 \equiv$ Tithymalus sect. Esula (Pers.) Prokh., Sist. Obzor Moloch. Sr. Azii: 166. $1933 \equiv$ Euphorbia subg. Keraselma Neck. ex Rchb., Consp. Regn. Veg. 1: 194. 1828 三 Keraselma (Neck. ex Rchb.) Raf., Fl. Tellur. 4: 116. $1838 \equiv$ Tithymalus subg. Keraselma (Neck. ex Rchb.) Prokh., Sist. Obzor Moloch. Sr. Azii: 118. 1933 - Type (designated here for $\boldsymbol{E}$. subg. Keraselma Neck. ex Rchb.): E. esula L. $=$ Allobia Raf. (see under Euphorbia sect. Paralias). $=$ Chylogala Fourr. $\equiv$ Tithymalus subg. Chylogala (Fourr.) Prokh. 1933 (see under E. sect. Chylogala).

$=$ Galarrhoeus Haw. (see under E. sect. Helioscopia).

$=$ Murtekias Raf. $\equiv$ Tithymalus subg. Murtekias (Raf.) Prokh.

1933 (see under E. sect. Myrsiniteae).

= Sclerocyathium Prokh. (see under E. sect. Sclerocyathium). $=$ Tithymalus Gaertn. (see under E. sect. Tithymalus).

$=T$. subg. Epurga Prokh. 1933 (see under E. sect. Lathyris).

$=T$. subg. Holophyllum Prokh. 1933 (see under E. sect. Holophyllum).

$=T$. subg. Paralias Raf. 1827 (see under E. sect. Paralias).

$=$ T. subg. Pythiusa Raf. 1838 (see under E. sect. Pythiusa).

$=T$. subg. Tulocarpa Raf. 1838 (see under E. sect. Helioscopia).

Annual or perennial herbs, sometimes shrubs, small trees, or pencil-stemmed succulents. Stem leaves mostly alternate, rarely opposite, without stipules. Stems (or new branches in the case of trees and shrubs) terminated by a pleiochasium bearing cyathia (lateral in E. osyridea). Cyathial glands 4 or 5 (occasionally up to 9 , or fewer than 4 , but these on plants with most cyathia bearing the normal number of glands), elliptic, trapezoidal, or semilunate, without appendages or with 2 or 
more claviform, knobby, digitate, or horn-like appendages, but never with petaloid appendages. Capsule ovoid to spherical, smooth to warty, glabrous to pilose. Seeds smooth to variously ornamented, usually carunculate, sometimes ecarunculate or with caruncle readily caducous.

In the morphological key to the sections of E. subg. Esula that follows, the most difficult groups to distinguish are those that have smooth capsules and cyathial glands with horn-like or other kinds of appendages. We use a combination of characters to separate them, but mostly rely upon differences in the seed sculpturing.

\section{Key to the sections of Euphorbia subg. Esula}

1. Dendroid shrubs with a generally rounded crown, or nearly leafless, succulent, pencil-stemmed shrubs ........... 2

1. Herbs, shrubs, or subshrubs, but never dendroid shrubs with a rounded crown and never nearly leafless, succulent, pencil-stemmed shrubs

2. Nearly leafless, succulent, gray-green to green, pencilstemmed shrubs .......... 17. E. sect. Aphyllis (in part)

2. Dendroid shrubs, usually with prominent, often deciduous leaves

3. Capsule with warty protuberances; cyathial glands elliptic, without appendages

4. E. sect. Helioscopia (E. mellifera, E. stygiana

E. sultan-hassei)

3. Capsule smooth or weakly papillose, without warty protuberances; cyathial glands trapezoidal or elliptic, usually with horn-like appendages but sometimes without them ..... 4

4. Stem tips reddish; seeds strongly compressed laterally; Mediterranean region

14. E. sect Pachycladae ( $E$. dendroides)

4. Stem tips green; seeds not compressed laterally; Macaronesia and westernmost Mediterranean region

17. E. sect. Aphyllis (in part)

5. Lower 1 or 2 pairs of stem leaves opposite, or all stem leaves decussate ................................... 6

5. All stem leaves alternate $\ldots \ldots \ldots \ldots \ldots \ldots \ldots \ldots \ldots \ldots \ldots \ldots$

6. Stems well developed, with many nodes of decussate leaves; capsule indehiscent, with spongy pericarp ........

1. E. sect. Lathyris

6. Stems usually quite short, with few nodes and with opposite, but not decussate leaves; capsule dehiscent, without

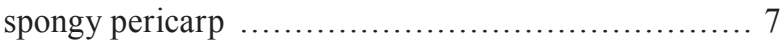

7. Capsule \pm trihedral, with sharply ribbed lobes, slightly trisulcate; seeds quadrangular .... 10. E. sect. Szovitsiae

7. Capsule with three rounded lobes, markedly trisulcate; seeds mostly hexangular or quadrangular .... ..... 12b. E. sect. Herpetorrhizae subsect. Oppositifolia

(most species)

8. Raylet leaves subtending the cyathia partly to largely con-

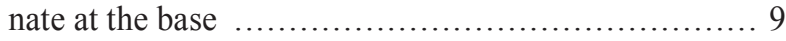

8. Raylet leaves subtending the cyathia free ........... 11

9. Margins of stem leaves serrate; cyathial glands without horn-like appendages

8. E. sect. Calyptratae (E. connata)
9. Margins of stem leaves entire; cyathial glands with hornlike appendages 10

10. Generally robust perennial herbs, sometimes woody at the base, often hairy; seeds smooth; native to Eurasia

11. E. sect. Patellares

10. Small annual herbs; glabrous; seeds usually pitted or grooved, rarely smooth; native to the New World

19. E. sect. Tithymalus (in small part)

11. Capsule verrucose or tuberculate .................. 12

11. Capsule smooth or finely granulate to weakly papillose .............................................. 13

12. Cyathial glands elliptic to rounded, without appendages 4. E. sect. Helioscopia (in large part)

12. Cyathial glands trapezoidal, with two claviform appendages ....................... 15. E. sect. Biumbellatae

13. Cyathial glands without appendages .............. 14

13. Cyathial glands with horn-like, knob-like, or digitate

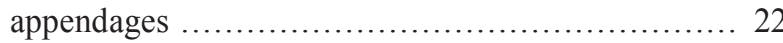

14. Seeds blackish or brownish, usually shiny .......... 15

14. Seeds mostly grayish, not shiny $\ldots \ldots \ldots \ldots \ldots \ldots \ldots \ldots . . . . .17$

15. Margins of leaves, at least near the apex, more or less serrulate or denticulate ... 4. E. sect. Helioscopia (in part)

15. Margins of leaves entire or undulate .............. 16

16. Annuals; cyathial glands minute ... 2. E. sect. Lagascae

16. Perennials; cyathial glands well developed 3. E. sect Holophyllum

17. Cyathial glands 5 ........... 7. E. sect. Sclerocyathium

17. Cyathial glands 4 (rarely fewer) .................... 18

18. Seeds without an evident caruncle, covered by whitish or grayish, longitudinally denticulate-lacerate spongy wings ...................... 13. E. sect. Guyonianae

18. Seeds carunculate, without spongy covering ......... 19

19. Seed with a longitudinally sulcate caruncle as long as the seed ............. 8. E. sect. Calyptratae (E. calyptrata)

19. Seed with a caruncle shorter than the seed ........... 20

20. Margins of leaves entire ... 6. E. sect. Pithyusa (in part)

20. Margins of leaves serrate to denticulate ............ 21

21. Annuals; margins of leaves serrulate to denticulate ...... 4. E. sect. Helioscopia (in part)

21. Perennials; margins of leaves markedly serrate .......... .................... 9. E. sect. Chylogala (E. serrata)

22. Stem leaves generally fleshy or else filiform (E. aleppica); cyathial glands with 2 knobs or many finger-like lobes (2 horn-like appendages in E. aleppica); male flowers without subtending bracteoles ........... 5. E. sect. Myrsiniteae

22. Stem leaves usually not fleshy, cyathial glands with 2 hornlike appendages; male flowers with subtending bracte-

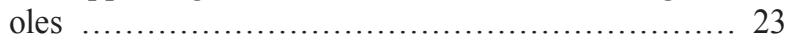

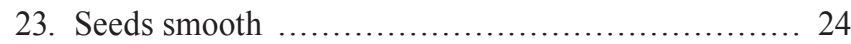

23. Seeds ornamented in some way or sulcate ........... 29

24. Caruncle large ( $>$ half the width of the seed), the seed notably asymmetrical and truncate on the upper ventral surface where the caruncle is located

14. E. sect. Pachycladae (E. terracina)

24. Caruncle less than half the width of the seed, or if larger, then the seed symmetrical and not markedly truncate near

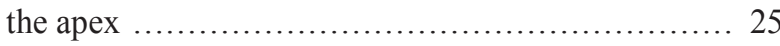


25. Plants annual 19. E. sect. Tithymalus (E. helleri)

25. Plants perennial .. 26

26. Plants densely branched, main stem not evident; native to beaches of the New World (Caribbean)

18. E. sect. Paralias (E. trichotoma)

26. Plants unbranched or moderately branched, main stem evident; native to the Old World .................... 27

27. Cyathial glands mostly semilunate, sometimes trapezoidal; leaf venation mostly prominent; capsule ovoid, deeply 3-lobed .............. 21. E. sect. Esula (most species)

27. Cyathial glands elliptic or trapezoidal; leaf venation obscure; capsule conical or nearly so, not deeply lobed .. 28

28. Seeds with a large, erect caruncle (more than one-third the length of the seed); involucral lobes deeply dissected (with the exception of E. retusa) ........ 9. E. sect. Chylogala

28. Seeds with a smaller caruncle; involucral lobes only slightly dissected or entire... 6. E. sect. Pithyusa (in part)

29. Capsule winged on the ridges of the cocci 19. E. sect. Tithymalus (in part)

29. Capsule not winged .

30. Native to the New World 19. E. sect. Tithymalus (in large part)

30. Native to the Old World 31

31. Plants annual ...................................... 32

31. Plants perennial ............................... 34

32. Seeds with conical, cylindrical, or elongated vermiculariform tubercles 16. E. sect. Exiguae

32. Seeds longitudinally sulcate, reticulate-foveolate, or irregularly tuberculate-rugulose $\ldots \ldots \ldots \ldots \ldots \ldots \ldots \ldots . \ldots . \ldots 33$

33. Seeds reticulate-foveolate ...... 18. E. sect. Paralias (E. ledebourii, E. taurinensis)

33. Seeds longitudinally sulcate or irregularly tuberculaterugulose 20. E. sect. Arvales

34. Seeds strongly and densely tuberculate 16. E. sect. Exiguae (E. rimarum)

34. Seeds foveolate or rugose ........................ 35

35. Capsule conic or nearly so, slightly trilobate, cyathial glands elliptic or trapezoidal; leaf venation obscure, palmate ................... 6. E. sect. Pithyusa (in part)

35. Capsule subcylindrical, ovoid or rarely conic, prominently trilobate, cyathial glands trapezoidal or semilunate; leaf venation prominent, if obscure, not palmate ......... 36

36. Cyathial glands semilunate, rarely trapezoidal, appendages brownish, yellowish, or purple; seeds shallowly foveolate.

......21. E. sect. Esula (in part, mainly African species)

36. Cyathial glands trapezoidal, appendages whitish; seeds deeply foveolate or foveolate-rugose ............. 37

37. Seeds subquadrangular in cross-section, reticulate-foveolate; mostly Mediterranean plants of maritime habitats 18. E. sect. Paralias

37. Seed subhexagonal in cross-section with concave, foveolate-rugose facets; plants of central Asia and the Iranian Highlands

...... 12. E. sect. Herpetorrhizae (E. subsect. Aucheriae and E. kanaorica in E. subsect. Oppositifoliae)
1. Euphorbia sect. Lathyris Dumort., Fl. Belg.: $87.1827 \equiv$ Tithymalus subg. Epurga Prokh., Sist. Obzor Moloch. Sr. Azii: 56. $1933 \equiv E$. sect. Epurga (Prokh.) Prokh. in Komarov, Fl. URSS 14: 479. 1949, nom. superfl. $\equiv E$. subsect. Decussatae Boiss. in Candolle, Prodr. 15(2): 99. 1862 $\equiv$ E. sect. Decussatae (Boiss.) Hurus. in J. Jap. Bot. 16(6): 339. 1940, nom. superfl. - Type: E. lathyris L.

Annual herbs, glabrous and glaucous. Stem leaves opposite, decussate, linear-lanceolate, margin entire, venation pinnate, prominent. Raylet leaves 2, free. Cyathial glands 4, semilunate, margin entire, with 2 rounded, knobby appendages; staminate flowers lacking bracteoles. Capsule indehiscent, subspherical, smooth, with a spongy pericarp, glabrous. Seeds ovoid, minutely reticulate-rugose, blackish, carunculate. $2 n=20$.

\section{Included species (1). - E. lathyris L.}

Distribution and habitat. - Found mostly in cultivation or near human settlements, in two main areas: eastern Asia and the Mediterranean, but also widely distributed by humans and found in temperate or subtropical regions worldwide.

Euphorbia lathyris (Fig. 2E) is unique in the subgenus in having stems with decussate leaves and indehiscent fruits with a spongy pericarp. The lack of bracteoles on the male flowers is a character shared with E. sect. Myrsiniteae (Khan, 1964). Prokhanov (1949: 480) mentioned that the species is found in countries of the Far East not only in cultivation as an oil plant, but possibly in the wild as well; he speculated that it could have been introduced into Europe during the Middle Ages.

2. Euphorbia sect. Lagascae Lázaro, Comp. Fl. Españ. 2: 282. 1896 - Type: E. lagascae Spreng.

= Euphorbia subsect. Phymatospermae Geltman, Novosti Sist. Vyssh. Rast. 32: 107. 2000 - Type: E. phymatosperma Boiss. \& Gaill.

Annual herbs, glabrous. Stem leaves alternate, linear to oblong-elliptic, margin entire, venation pinnate, prominent. Raylet leaves 2, free. Cyathial glands 4, minute, narrowly elliptic, margin entire, without appendages. Capsule ovoid or subconical, smooth, glabrous. Seeds subcylindrical to ovoid, slightly depressed to quadrangular, smooth or minutely tuberculate-rugulose and transversely sulcate, blackish, carunculate. $2 n=16$.

Included species (3). - E. hyrcana Grossh., E. lagascae Spreng., E. phymatosperma Boiss. \& Gaill.

Distribution and habitat. - Canary Islands, Mediterranean region, and western part of Iranian highlands, in grasslands and ruderal habitats.

3. Euphorbia sect. Holophyllum (Prokh.) Prokh. in Komarov, Fl. URSS 14: 337. 1949 ETithymalus subg. Holophyllum Prokh., Sist. Obzor Moloch. Sr. Azii: 68. 1933 - Type (designated by Wheeler in Amer. Midl. Naturalist 30: 489. 1943): T. blepharophyllus (Ledeb.) Klotzsch \& Garcke (三E. blepharophylla Ledeb.).

= Euphorbia subsect. Verticillatae Hurus. in J. Jap. Bot. 16: 344. 1940 - Type: E. fischeriana Steud. (=E. pallasii Turcz.) 
Perennial herbs, glabrous or hairy. Stem leaves alternate, lower ones scale-like, medium and upper ones expanded, usually persistent, margin usually entire, venation pinnate, prominent. Raylet leaves 2, free. Cyathial glands 4 or 5, well developed, elliptic or reniform, margin sometimes undulate, without appendages. Capsule ovoid or subconical, somewhat woody when ripe, smooth or slightly rugulose, never verrucose, glabrous. Seeds ovoid, smooth, brown or black, carunculate. $2 n=18,20$.

Included species (27). - E. blepharophylla Ledeb., E. ebracteolata Hayata, E. ferganensis B. Fedtsch, E. griffithii Hook. f., E. himalayensis (Klotzsch) Boiss., E. isatidifolia Lam., E. jacquemontii Boiss., E. kansuensis Prokh., E. kingdonwardii Binojkumar \& N.P. Balakr., E. komaroviana Prokh., E. lipskyi (Prokh.) Prokh., E. luteoviridis D.G. Long, E. megalocarpa Rech.f., E. mongolica (Prokh.) Prokh., E. monocyathium (Prokh.) Prokh., E. pallasii Turcz., E. rapulum Kar. \& Kir., E. rosularis Fed., E. rupestris Ledeb., E. sarawschanica Regel, E. sharmae Battacharyya, E. sikkimensis Boiss., E. stracheyi Boiss., E. thomsoniana Boiss., E. tianshanica (Prokh.) Popov, E. wallichii Hook.f., E. yaroslavii Poljakov.

Distribution and habitat. - Mountainous areas of eastern and central Asia, the Himalayas, southern Siberia, northeast China, Korea, and Japan, with one species disjunct in the Iberian Peninsula; in forests, steppes, on rock outcrops, and in alpine meadows.

Members of E. sect. Holophyllum vary widely in size, from diminutive rosette plants such as E. stracheyi (Fig. 2A) to robust, showy herbs such as $E$. wallichii. The taxonomy of several of the Himalayan species groups, particularly ones such as E. stracheyi and E. thomsoniana, is complex and in need of further study.

4. Euphorbia sect. Helioscopia Dumort., Fl. Belg.: 87.1827 $\equiv$ Galarrhoeus Haw., Syn. Pl. Succ.: 143. 1812 ('Galarhoeus') $\equiv$ Tithymalus sect. Galarrhoeus (Haw.) Klotzsch \& Garcke in Abh. Königl. Akad. Wiss. Berlin 1859: 17. 1860 , nom. superfl. $\equiv E$. subsect. Galarrhoeus (Haw.) Boiss. in Candolle, Prodr. 15(2): 173. 1862 ('Galarrhaei') $\equiv T$. sect. Pseudokeraselma Prokh., Sist. Obzor Moloch. Sr. Azii: 119. 1933, nom. superfl. - Type (designated for Galarrhoeus by Wheeler in Amer. Midl. Naturalist 30: 492. 1943): E. helioscopia L. (三 G. helioscopius (L.) Haw.). $=$ Tithymalus subg. Tulocarpa Raf., Fl. Tellur. 4: 115. $1838 \equiv$ T. sect. Tulocarpa (Raf.) Prokh., Sist. Obzor Moloch. Sr. Azii: 94. 1933 三 Euphorbia sect. Tulocarpa (Raf.) Prokh. in Komarov, Fl. URSS 14: 345. 1949 - Type: E. palustris L. $=$ Euphorbia sect. Chamaebuxus Lázaro, Comp. Fl. Españ. 2: 282. 1896 - Type: E. chamaebuxus Bern. (=E. pyrenaica Jord.).

= Tithymalus sect. Microsphaerae Prokh., Sist. Obzor Moloch. Sr. Azii: 117. 1933 ('Microsphaera') - Type: T. microsphaerus (Boiss.) Klotzsch \& Garcke (三Euphorbia microsphaera Boiss.).

Annual or perennial herbs, subshrubs, rarely shrubs or small trees, glabrous or hairy. Stem leaves alternate, ovate, oblong, oblanceolate, linear-lanceolate, obovate-spatulate, margin serrate, dentate or serrulate in the upper part of leaves, sometimes entire, venation pinnate, prominent. Raylet leaves 2-4, free. Cyathial glands 4 or 5, elliptic, margin entire, without appendages. Capsule 3-lobed to subglobose, most often verrucose or tuberculate, rarely smooth, glabrous or hairy. Seeds ovoid to sometimes subglobose, mostly smooth, sometimes ornamented or sculptured, brown or black, usually shiny, mostly carunculate. Various chromosome numbers have been reported for this section $(2 n=10,12,14,16,18,20,24,26,28,30,36,40,42,44)$.

Included species (136). - E. acanthothamnos Heldr. \& Sart. ex Boiss., E. adenochlora C. Morren \& Decne., E. akenocarpa Guss., E. alatavica Boiss., E. alpina Ledeb., E. alta Norton, $\boldsymbol{E}$. altaica Ledeb., E. altissima Boiss., E. angulata Jacq., E. anthula Lavrent. \& Papan., E. apios L., E. ardonensis Galushko, E. arguta Banks \& Sol., E. aristata Schmalh., E. austriaca A. Kern., E. austroanatolica Hub.-Mor. \& M.S. Khan, E. berythea Boiss. \& Blanche, E. bivonae Steud., E. blatteri Oudejans, E. buchtormensis Ledeb., E. capitulata Rchb., E. carniolica Jacq., E. carpatica Wol., E. cashmeriana Royle, E. ceratocarpa Ten., E. clementei Boiss., E. condylocarpa M. Bieb., E. coniosperma Boiss. \& Buhse, E. corallioides L., E. cornigera Boiss., E. cossoniana Boiss., E. cuneifolia Guss., E. cybirensis Boiss., E. czerepanovii Geltman, E. depauperata Hochst. ex A. Rich., E. dimorphocaulon P.H. Davis, E. djimilensis Boiss., E. donii Oudejans, E. dulcis L., E. dumalis S. Carter, E. duvalii Lecoq \& Lamotte, E. edgeworthii Boiss., E. epithymoides L., E. erinacea Boiss. \& Kotschy, E. eriophora Boiss., E. eugeniae Prokh., E. fauriei H. Lév. \& Vaniot, E. fistulosa M.S. Khan, E. flavicoma DC., E. fragifera Jan, E. gaditana Coss., E. gasparrinii Boiss., E. gebelica Brullo, E. glabriflora Vis., E. gregersenii K. Malý ex Beck, E. grisophylla M.S. Khan, E. hakutosanensis Hurus., E. haussknechtii Boiss., E. heishuiensis W.T. Wang, E. helioscopia L., E. hierosolymitana Boiss., E. hirsuta L., E. hyberna L., E. hylonoma Hand.-Mazz., E. illirica Lam., E. jenisseiensis Baikov, E. jolkinii Boiss., E. khasyana Boiss., E. kudrjaschevii (Pazij) Prokh., E. lamprocarpa (Prokh.) Prokh., E. lucorum Rupr., E. macrocarpa Boiss. \& Buhse, E. macrorhiza Ledeb., E. margalidiana Kuhbier \& Lewej., E. mazandaranica Pahlevani, E. melitensis Parl, E. mellifera Aiton, E. micractina Boiss., E. microsphaera Boiss., E. montenegrina (Bald.) K. Malý, E. mucronulata (Prokh.) Pavlov, E. nereidum Jahand. \& Maire, E. oblongata Griseb., E. orientalis L., E. oxyodonta Boiss., E. pachyrrhiza Kar. \& Kir., E. palustris L., E. paniculata Desf., E. papillaris (Boiss.) Raffaelli \& Ricceri, E. pekinensis Rupr., E. peltata Roxb., E. petitiana A. Rich., E. philippiana (Klotzsch \& Garcke) Boiss., E. physocaulos Mouterde, E. pilosa L., E. platyphyllos L., E. polychroma A. Kern., E. polygalifolia Boiss. \& Reut., E. procera M. Bieb., E. pseudoapios Maire \& Weiller, E. pseudosikkimensis (Hurus. \& Yu. Tanaka) Radcl.-Sm., E. pterococca Brot., E. purpurea (Raf.) Fernald, E. pyrenaica Jord., E. rhabdotosperma Radcl.-Sm., E. rhytidosperma Boiss. \& Balansa, E. sareciana M.G. Gilbert, E. schillingii Radcl.-Sm., E. schottiana Boiss., E. scripta Sommier \& Levier, E. semivillosa (Prokh.) Krylov, E. sendaica Makino, E. serpentini Novák, E. sintenisii Boiss. ex Freyn, E. sojakii (Chrtek \& Kř́isa) Dubovik, E. soongarica Boiss., 
E. spathulata Lam., E. spinosa L., E. squamigera Loisel., E. squamosa Willd., E. stricta L., E. stygiana H.C. Watson, E. subamplexicaulis Kar. \& Kir., E. sultan-hassei Strid \& al., E. talastavica (Prokh.) Prokh., E. tauricola Prokh., E. texana Boiss., E. togakusensis Hayata, E. transoxana (Prokh.) Prokh., E. ugandensis Pax \& K. Hoffm., E. uliginosa Welw. ex Boiss., E. valdevillosocarpa Arvat \& Nyár., E. valerianifolia Lam., E. velenovskyi Bornm., E. verrucosa $\mathrm{L}$., E. wittmannii Boiss. Distribution and habitat. - Most diverse across Eurasia and North Africa, but a few species also present in eastern Africa, Macaronesia, and the Americas. The range of habitats is very diverse, from montane forests to steppes, rocky outcrops and wetlands, with a few weedy species. Most species are associated with mountains and are fairly mesic, although some are widely distributed in lowland areas.

Our circumscription of E. sect. Helioscopia is largely consistent with that of Frajman \& Schönswetter (2011), but it includes a more expanded sampling, extending the section into Africa and the Americas. With the limited resolution of the two molecular markers used in this study, the overall relationships within the section are not well resolved. We therefore are not yet able to divide the section into a strongly supported series of monophyletic subsections.

5. Euphorbia sect. Myrsiniteae (Boiss.) Lojac., Fl. Sicul. 2(2): 345. $1907 \equiv E$. subsect. Myrsiniteae Boiss. in Candolle, Prodr. 15(2): 173. $1862 \equiv$ Murtekias Raf., Fl. Tellur. 4: 116. $1838 \equiv$ Tithymalus subg. Murtekias (Raf.) Prokh., Sist. Obzor Moloch. Sr. Azii: 206. $1933 \equiv$ E. sect. Murtekias (Raf.) Prokh. in Komarov, Fl. URSS 14: 391. 1949, nom. superfl. - Type: E. myrsinites L. (”M. myrsinites (L.) Raf.). Perennial herbs (annual in E. aleppica), glabrous, usually papillose. Stem leaves alternate, oblong-lanceolate, oblongovate, suborbicular, ovate to obovate, rarely linear, margin entire or denticulate, more or less fleshy or at least semisucculent, venation obscurely palmate. Raylet leaves 2 , free. Cyathial glands 4, oblong-elliptic, margin entire, with 2 knobby or spatulate appendages or distal margin deeply divided with numerous finger-like lobes, or two horn-like appendages in E. aleppica; staminate flowers lacking bracteoles. Capsule ovoid-conical or subglobose, smooth or granulate, glabrous. Seeds ovoid-quadrangular, smooth, rugulose, or minutely tuberculate, grayish, carunculate (but readily caducous and appearing ecarunculate in E. aleppica). $2 n=20$.

Included species (14). - E. aleppica L., E. anacampseros Boiss., E. corsica Req., E. craspedia Boiss., E. denticulata Lam., E. fontqueriana Greuter, E. marschalliana Boiss., E. monostyla Prokh., E. myrsinites L., E. oxyphylla Boiss., E. rechingeri Greuter, E. rigida $\mathrm{M}$. Bieb., E. spinidens Bornm. ex Prokh., E. veneris M.S. Khan.

Distribution and habitat. - Mediterranean region, Caucasus to the Iranian highlands, usually growing in dry, exposed, rocky habitats.

Our circumscription of the section agrees with that of Frajman \& Schönswetter (2011), except for the notable addition of E. aleppica (Fig. 2B), which is an annual species. Although the cauline leaves and annual habit of E. aleppica are notably distinct from those of members of the rest of the section, the raylet leaves are fleshy and palmately veined like in other members of the section. The other species in the section are characterized by their perennial habit, glaucous, palmately veined, rather succulent leaves and cyathial glands with short, clavate or dentate appendages. A notable synapomorphy for the section is the lack of bracteoles subtending the male flowers in the cyathia (Pahlevani \& al., 2011).

6. Euphorbia sect. Pithyusa (Raf.) Lázaro, Comp. Fl. Españ. 2: 282.1896 ETithymalus subg. Pithyusa Raf., Fl. Tellur. 4: 116. 1838 ('Pythiusa') $\equiv T$. sect. Pithyusa (Raf.) Prokh., Sist. Obzor Moloch. Sr. Azii: 82. 1933 ('Pythiusa') - Type: E. pithyusa L.

$=$ Tithymalus sect. Conicocarpi Prokh., Sist. Obzor Moloch. Sr. Azii: 155. 1933 ('Conicocarpus') $\equiv$ Euphorbia subsect. Conicocarpae (Prokh.) Prokh. in Komarov, Fl. URSS 14: 392. $1949 \equiv$ E. sect. Conicocarpae (Prokh.) Frajman in Molec. Phylogen. Evol. 61: 421. 2011 - Type (designated by Wheeler in Amer. Midl. Naturalist 30: 490. 1943): E. humilis Ledeb.

= Tithymalus sect. Cymatospermum Prokh., Sist. Obzor Moloch. Sr. Azii: 151. 1933 E Euphorbia sect. Cymatospermum (Prokh.) Prokh. in Komarov, Fl. URSS 14: 459. 1949 - Type: E. falcata.

Perennial or rarely annual herbs, sometimes lignescent at the base, glabrous, usually papillose. Stem leaves alternate, linear and scale-like to elliptic or ovate, margin usually entire, sometimes serrulate, venation obscurely palmate. Raylet leaves 2, free. Cyathial glands 4, elliptic, trapezoid-elliptic, reniform or semilunate, margin entire, with or without hornlike appendages. Capsule conical or nearly so, rounded, smooth, rarely granulate, glabrous or pilose. Seeds ovoid, oblong, or ellipsoid, mostly subquadrangular in cross-section, smooth to foveolate, rarely transversely sulcate, grayish, carunculate. $2 n$ $=16,18,28,36,40,72$.

Included species (50). - E. acanthodes Akhani, E. barrelieri Savi, E. boetica Boiss., E. bupleuroides Desf., E. cassia Boiss., E. chaborasia Gomb., E. cheiradenia Boiss. \& Hohen., E. erythradenia Boiss., E. erythrodon Boiss. \& Heldr., E. falcata L., E. gaillardotii Boiss. \& Blanche, E. gedrosiaca Rech.f. \& al., E. glareosa Pall. ex M. Bieb., E. gypsicola Rech.f. \& Aellen, E. hercegovina Beck, E. humilis Ledeb., E. iranshahri Pahlevani, E. kerneri Huter ex A. Kern., E. kopetdaghi (Prokh.) Prokh., E. macroclada Boiss., E. malleata Boiss., E. malurensis Rech.f., E. matritensis Boiss., E. microsciadia Boiss., E. minuta Loscos \& Pardo, E. nicaeensis All., E. niciciana Borbás ex Novák, E. obovata Decne., E. orphanidis Boiss., E. panjutinii Grossh., E. pannonica Host, E. pestalozzae Boiss., E. petrophila C.A. Mey., E. pisidica Hub.-Mor. \& M.S. Khan, E. pithyusa L., E. plebeia Boiss., E. polycaula Boiss. \& Hohen., E. prolifera Buch.-Ham. ex D. Don, E. sahendii Bornm., E. saxatilis Jacq., E. saxicola Radcl.-Sm., E. seguieriana Neck., E. smirnovii Geltman, E. sogdiana Popov, E. spartiformis Mobayen, E. stepposa Zoz, E. teheranica Boiss., E. thessala (Formánek) Degen \& Dörfl., E. transtagana Boiss., E. triflora Schott \& al. 
Distribution and habitat. - Mainly Mediterranean and neighboring areas, Iranian highlands and montane regions of central Asia, with a few species in the steppe zone of Eurasia and in the mountains of eastern Asia (at least as far east as Thailand); on rocky (calcareous) substrates, in steppes and steppe-like grasslands, deserts, dry scrub, and gypsum hills, sometimes weedy.

Frajman \& Schönswetter (2011) designated a new E. sect. Conicocarpae for this group, but they failed to realize that Lázaro's E. sect. Pithyusa was already available. The group typically consists of small perennials with faintly palmately veined, coriaceous leaves, smooth to granulate capsules, and a tendency towards succulence (Fig. 2G). However, E. falcata and E. gaillardotii are both annuals. Euphorbia sanctae-catharinae Fayed, from mountains in the Sinai Peninsula, likely also belongs here, but it also bears some resemblance to $E$. sect. Paralias. Likewise, E. antilibanotica Mouterde from Syria, E. cuspidata Bertol. from the eastern Mediterranean to Iraq, and E. elymaitica Bornm. from Iran are other possible members of this section.

7. Euphorbia sect. Sclerocyathium (Prokh.) Prokh. in Komarov, Fl. URSS 14: 336. 1949 三 Sclerocyathium Prokh., Sist. Obzor Moloch. Sr. Azii: 30. 1933 - Type: S. popovii Prokh. (三E. sclerocyathium Korovin \& Popov).

= Euphorbia subsect. Tibeticae Prokh. in Komarov, Fl. URSS 14: 737. 1949 - Type: E. tibetica Boiss.

Perennial or occasionally annual herbs, glabrous. Stem leaves alternate, oblong to ovate or elliptic, margin irregularly serrate to entire, venation mostly obscure. Raylet leaves 2 , free. Cyathial glands 5, elliptic or oblong, margin entire, without appendages. Capsule ovoid to conical, mostly smooth, rarely slightly verrucose, glabrous. Seeds ovoid, smooth, grayish, sometimes spotted, carunculate. $2 n=20$.

Included species (9). - E. altotibetica Paulsen, E. bungei Boiss., E. caeladenia Boiss., E. grossheimii (Prokh.) Prokh., E. kozlovii Prokh., E. schugnanica B. Fedtsch., E. sclerocyathium Korovin \& Popov, E. tibetica Boiss., E. turkestanica Regel.

Distribution and habitat. - Southwestern and central Asia, including the Himalayas; on dry stony mountain slopes, sometimes in steppes.

Euphorbia sclerocyathium was separated into an independent genus by Prokhanov (1933) and later treated as a monotypic section in Euphorbia (Prokhanov, 1949, 1964). Euphorbia schugnanica (endemic to Tajikistan and northern Afghanistan) has remnants of warts on the fruit surface, a character that is characteristic of E. sect. Helioscopia.

\section{Euphorbia sect. Calyptratae Geltman, sect. nov. - Type:} E. calyptrata Coss. \& Durieu.

Perennial or occasionally annual herbs, glabrous. Stem leaves alternate, linear, oblong or semi-rounded, margin serrate, venation obscure. Raylet leaves 2 , free or connate. Cyathial glands 4, oblong or rounded, margin coarsely undulate, without horn-like appendages. Capsule subconical to almost rounded, smooth, glabrous. Seeds ovoid, smooth, grayish, with a large, longitudinally sulcate caruncle. $2 n=40$.
Included species (2). - E. calyptrata Coss. \& Durieu, E. connata Boiss.

Distribution and habitat. - Deserts and steppes of northern Africa (E. calyptrata) and Iran (E. connata).

The connate raylet leaves found in E. connata are also a synapomorphy for $E$. sect. Patellares.

9. Euphorbia sect. Chylogala (Fourr.) Prokh. in Komarov, Fl. URSS 14: 384. 1949 E Chylogala Fourr. in Ann. Soc. Linn. Lyon, ser. 2, 17: 150. $1869 \equiv$ E. subsect. Carunculares Boiss. in Candolle, Prodr. 15(2): 111. $1862 \equiv$ Tithymalus subg. Chylogala (Fourr.) Prokh., Sist. Obzor Moloch. Sr. Azii: $57.1933 \equiv$ E. sect. Carunculares (Boiss.) Tutin in Feddes Repert. 79: 55. 1968, nom superfl. - Type (designated for E. subsect. Carunculares by Wheeler in Amer. Midl. Naturalist 30: 492. 1943): E. serrata L.

Perennial herbs, glabrous. Stem leaves alternate, linear or oblong to ovate, margin serrate to entire, venation mostly obscure. Raylet leaves 2, free. Cyathial glands 4 or rarely 2, 3 , or 5 , oblong, semilunate, elliptic or suborbicular, margin entire, usually with 2 or more horn-like appendages, or without appendages. Capsule subconical or ovoid, smooth or granulate, glabrous. Seeds cylindrical or nearly so, smooth, grayish, the caruncle usually large, sometimes approaching the size of the seed itself. $2 n=18$.

Included species (4). - E. alaica (Prokh.) Prokh., E. heteradena Jaub. \& Spach, E. retusa Forssk., E. serrata L.

Distribution and habitat. - Mediterranean region, Arabian Peninsula, southwestern and central Asia (to northern PamirAlay and western Tien-shan); in deserts and steppes, on stony mountain slopes and by dry streams, or in fallow fields.

10. Euphorbia sect. Szovitsiae Geltman, sect. nov. - Type: E. szovitsii Fisch. \& C.A. Mey.

Annual herbs, glabrous. Stem leaves alternate, the lowest sometimes opposite, linear-spatulate, margin entire, venation obscure. Raylet leaves 2, free. Cyathial glands 4(5), semilunate, margin entire, with 2 short horn-like appendages. Capsule subovoid, smooth, glabrous, usually ribbed and puncticulate along the dorsal side of the cocci. Seeds oblong, quadrangular in cross-section, irregularly transversely rugose or tuberculate on the facets, whitish, carunculate. $2 n=20$.

Included species (1): E. szovitsii Fisch. \& C.A. Mey.

Distribution and habitat. - Caucasus, Turkey, Iranian highlands, southern part of central Asia; on gravel slopes, screes, stream beds, or in steppes.

11. Euphorbia sect. Patellares (Prokh.) Frajman in Molec. Phylogen. Evol. 61: 422. $2011 \equiv$ E. subsect. Patellares Prokh. in Komarov, Fl. URSS 14: 743. 1949 - Type: E. amygdaloides L.

Perennial herbs, sometimes woody at the base, glabrous or hairy. Stem leaves alternate, linear to elliptic or ovate, margin entire, venation pinnate, mostly prominent. Raylet leaves 2 , partly to considerably connate at base. Cyathial glands 4, semilunate, falcate or trapezoid, margin entire, with 2 hornlike appendages. Capsule ovoid or nearly so, deeply trilobed, 
smooth or minutely granulate, glabrous or hairy. Seeds ovoid or oblong to subspherical, smooth, grayish, carunculate. $2 n=$ $16,18,20,40$.

Included species (14).- E. amygdaloides L., E. characias L., E. davisii M.S. Khan, E. durandoi Chabert, E. erubescens Boiss., E. glaberrima K. Koch, E. heldreichii Orph. ex Boiss., E. kotschyana Fenzl, E. macroceras Fisch. \& C.A. Mey., E. melapetala Gasp. ex Guss., E. oblongifolia (K. Koch) K. Koch, E. orjeni Beck, E. semiperfoliata Viv., E. thompsonii Holmboe.

Distribution and habitat. - Mediterranean region and mountains of central Europe, the Balkan Peninsula, Caucasus, and Iranian highlands; in forests and montane meadows or rocky habitats.

Prokhanov (1949) and Radcliffe-Smith (1982) included these species in E. sect. Esula, but molecular evidence does not show a close affinity to that section. Morphologically, E. sect. Patellares differs in its connate raylet leaves and generally robust habit, and the lower stem leaves in some species are tightly grouped into a pseudorosette.

12. Euphorbia sect. Herpetorrhizae (Prokh.) Prokh. in Komarov, Fl. URSS 14: 456.1949 ('Herpetorrhiza') $\equiv$ Tithymalus sect. Herpetorrhizi Prokh., Sist. Obzor Moloch. Sr. Azii: 56. 142.1933 ('Herpetorrhiza') - Type: T. herpetorrhizus Prokh. (三E. aucheri Boiss.).

=Euphorbia sect. Oppositifoliae (Boiss.) Baikov 2007 (see under E. subsect. Oppositifoliae).

Annual to perennial herbs, glabrous or hairy. Stem leaves alternate or opposite, linear to suborbicular or spatulate, margin entire or minutely serrate, venation obscure. Raylet leaves 2 , usually free, rarely partly connate at base. Cyathial glands 4, trapezoid or elliptic, margin entire, with or without horn-like appendages. Capsule ovoid, smooth, glabrous. Seeds oblong, quadrangular to hexangular in cross-section, longitudinally sulcate or rugose, irregularly foveolate-rugose or tuberculate, brownish, carunculate or ecarunculate.

In the combined analysis, there are two distinct subclades in this section that have differences in morphology; we therefore recognize them as two subsections.

\section{Key to the subsections of $E$. sect. Herpetorrhizae}

1a. Perennials; stem leaves alternate ........................... 12a. E. subsect. Aucheriae

1b. Annuals (perennial in E. kanaorica); lowermost leaves on stem in 1 or 2 opposite pairs

12b. E. subsect. Oppositifoliae

12a. Euphorbia subsect. Aucheriae Geltman \& Pahlevani, subsect. nov. - Type: E. aucheri Boiss.

Perennial herbs. Stem leaves alternate, linear to suborbicular, persistent, serrate to subentire. Raylet leaves 2, free. Cyathial glands with 2 whitish, rather long, acute, horn-like appendages. Seeds subhexangular in cross-section, with concave, foveolate-rugulose facets, carunculate (the caruncle obliquely joined to the seed).
Included species (2). - E. aucheri Boiss., E. deltobracteata (Prokh.) Prokh.

Distribution and habitat. - Iranian highlands, PamirAlay (Tajikistan); mainly on mountain slopes and screes, and in steppes.

12b. Euphorbia subsect. Oppositifoliae Boiss. in Candolle, Prodr. 15(2): 99. $1862 \equiv$ E. sect. Oppositifoliae (Boiss.) Baikov, Molochai Sev. Azii: 114. $2007 \equiv$ Tithymalus sect. Oppositifolii (Boiss.) Prokh., Sist. Obzor Moloch. Sr. Azii: 122. 1933 ('Oppositifolium') - Type (designated by Wheeler in Amer. Midl. Naturalist 30: 492. 1943): E. inderiensis Kar. \& Kir. (“E. pygmaea Fisch. \& C.A. Mey.”, nom. nud.).

= Euphorbia subsect. Densiusculae Prokh. in Komarov, Fl. URSS 14: 743. 1949 - Type: E. densiuscula M. Pop.

Annual or rarely perennial (E. kanaorica) herbs. Stem leaves linear or obovate to spatulate, often few, entire, soon deciduous, lower 1 or 2 pairs opposite, sometimes alternate leaves present above the lower opposite ones. Raylet leaves 2 , usually free, very rarely fused at the base, usually on repeatedly branched rays, exceeding the stem in length. Cyathial glands elliptic or semilunate, with 2 short horns or hornless. Seeds hexangular or rarely quadrangular in cross-section, longitudinally sulcate on the facets and transversally plicate-rugose, sometimes tuberculate, carunculate or ecarunculate. $2 n=10,16$.

Included species (10). - E. aserbajdzhanica Bordz., E. consanguinea Schrenk, E. densa Schrenk, E. densiuscula M. Pop., E. densiusculiformis (Pazij) Botsch., E. inderiensis Less. ex Kar. \& Kir., E. kanaorica Boiss., E. sororia Schrenk, E. triodonta (Prokh.) Prokh., E. turczaninowii Kar. \& Kir.

Distribution and habitat. - Asia, from Turkey and Caucasus to Kuwait, Pakistan, and Afghanistan, and into western China; on sand, clay and saline soils in deserts and steppes, and on stony slopes of mountains.

This group is morphologically very distinct, and most species (except $E$. densiusculiformis) have very short stems (usually just 2 to 4 nodes), with the plant body formed mainly by much branched apical or sometimes axillary rays.

13. Euphorbia sect. Guyonianae Molero \& Riina, sect. nov. - Type: E. guyoniana Boiss. \& Reut.

Perennial herbs (much-branched from the base), glabrous. Stem leaves alternate, laxly spaced, soon deciduous, linearelliptic, margin entire, venation obscure. Raylet leaves 2, free. Cyathial glands 4, transversely oblong to suborbicular, with slightly denticulate or undulate margin, without horn-like appendages. Capsule subspherical, usually asymmetrical (due to abortion of one of the seeds), sometimes with longitudinal grooves, smooth, glabrous. Seeds ovoid, unique in possessing a spongy covering of arillate origin that turns into longitudinal denticulate-lacerate wings, whitish or grayish, ecarunculate. $2 n=16$.

Included species (1). - E. guyoniana Boiss. \& Reut.

Distribution and habitat. - Northwestern Africa (Morocco to Libya); dunes and sandy areas on the northern edge of the Saharan Desert. 
Because of its unique seed morphology (Fig. 2T) and cyathial glands without appendages, which are present in the sister sections E. sect. Pachycladae and sect. Biumbellatae, E. guyoniana is treated as a monotypic section.

14. Euphorbia sect. Pachycladae (Boiss.) Tutin in Feddes Repert. 79: 54. $1968 \equiv$ E. subsect. Pachycladae Boiss. in Candolle, Prodr. 15(2): 107. 1862 - Type (designated by Wheeler in Amer. Midl. Naturalist 30: 492. 1943): E. dendroides $\mathrm{L}$.

$=$ Euphorbia subsect. Terracinae Geltman in Novosti Sist. Vyssh. Rast. 33: 155. 2001 - Type: E. terracina L.

Perennial herbs or semisucculent, dendroid shrubs up to $3 \mathrm{~m}$ tall, glabrous; in dendroid shrubs the ends of branches reddish or rarely grayish (not chlorophyllous). Stem leaves alternate, sparse or laxly clustered towards tips of branches, polymorphous, margin entire to serrulate, venation obscurely pinnate, midrib prominent, deciduous in summer (E. dendroides). Raylet leaves 2 , free and prominent. Cyathial glands 4 , polymorphous, margin entire, without appendages or rarely with 2 short horns (E. dendroides), with 2 setaceous horns or rarely without appendages (E. terracina). Capsule subspherical and markedly sulcate, smooth or puncticulate (granulate) on the dorsal side of the cocci, glabrous. Seeds ellipsoid (E. terracina) or strongly compressed laterally (E. dendroides), smooth, grayish, caruncle obnavicular, large and excentric in E. terracina. $2 n=18,36$.

Included species (2). - E. dendroides L., E. terracina L.

Distribution and habitat. - Circum-Mediterranean region; both species are mainly littoral, but can penetrate up to $100 \mathrm{~km}$ inland. They occur in summer-arid areas, on coastal sands in littoral scrub, on edges of roads and trails, on substrates of siliceous, schistose, gypseous, volcanic, or calcareous origin, from sea level to $800 \mathrm{~m}$.

Both E. dendroides and E. terracina have distinctive, smooth seeds with large caruncles. They also share a similar geographical distribution, and the same chromosome number has been reported for both species $(2 n=18)$. This chromosome number, the laterally compressed seeds, and the reddish, striated ultimate branches distinguish $E$. dendroides from similarlooking species in E. sect. Aphyllis.

15. Euphorbia sect. Biumbellatae Molero \& Riina, sect. nov. - Type: E. biumbellata Poir.

Perennial herbs (multi-stemmed), glabrous. Stem leaves alternate, sparse, oblong, lanceolate-oblong or linear-oblong, margin entire to denticulate, venation obscurely pinnate, midrib prominent. Raylet leaves 2, free. Cyathial glands 4, trapezoid, margin entire, with 2 divergent, claviform appendages. Capsule subglobose to ovoid, slightly to strongly sulcate, uniformly granulose or laxly verrucose, with large cylindrical or irregular warts, glabrous. Seeds ellipsoid to subcylindrical, the surface vermiculate, with linear tubercles aligned longitudinally or in a reticulate arrangement, brownish, carunculate. $2 n=14,26$.

Included species (3). - E. biumbellata Poir., E. briquetii Emb. \& Maire, E. megalatlantica Ball.

Distribution and habitat. - Endemic to the western Mediterranean region (Spain, France, Italy, Algeria, Morocco, Tunisia); subruderal, along roadsides, slopes, cultivated areas, rocky river beds, or dry montane grasslands, from sea level to $3000 \mathrm{~m}$.

This is a well-defined section with characteristic seeds (Fig. 2U) and often a double pleiochasial synflorescence.

16. Euphorbia sect. Exiguae (Geltman) Riina \& Molero, stat. nov. $\equiv$ E. subsect. Exiguae Geltman in Novosti Sist. Vyssh. Rast. 32: 101. 2000 - Type: E. exigua L.

Annual (or perennial in E. rimarum) herbs, glabrous. Stem leaves alternate, densely imbricate or sparsely spaced, polymorphous (generally linear-elliptic or linear-cuneate, with considerable variation in the apex), margin entire or finely serrulate, venation obscurely pinnate, midvein prominent. Raylet leaves 2 , free. Cyathial glands 4 or 5 , semicircular to elliptic, margin entire, with 2 thin, divergent, horn-like appendages. Capsule ovoid, ovoid-oblongoid to subspherical, smooth or finely granulate on a narrow strip along the dorsal line of the cocci, glabrous or hairy. Seeds ovoid-subtetragonal, ovoidoblongoid to ellipsoid, keeled on the dorsal side, subquadrangular to suborbicular in cross-section, surface with conical tubercles or acute or rounded cylinders, or elongated vermiculiform (sometimes anastomosing), grayish or brownish, carunculate (the caruncle sometimes quickly deciduous in E. exigua or lacking in E. nurae). $2 n=16,18,20,24,28,40,56,64$.

Included species (5). - E. dracunculoides Lam., E. exigua L., E. medicaginea Boiss., E. nurae P. Fraga \& Rossello, E. rimarum Coss. \& Balansa.

Distribution and habitat. - Southern Europe, northern Africa, Asia, Macaronesia, Mauritius, the Comoros, and Madagascar; in grasslands, rocky or sandy subdeserts, rock fissures in mountains, weedy areas, abandoned cultivated areas, from sea level to $2200 \mathrm{~m}$.

This section is circumscribed here based on the ITS topology and characters such as leaf morphology and seed shape and ornamentation (Fig. 2V). Euphorbia dracunculoides, the most widespread species of the section, was originally described from Mauritius ("Ile de France" in the protologue), however we suspect the species is not native to those islands. Additional revisionary work is needed in this variable species to clarify species limits.

17. Euphorbia sect. Aphyllis Webb \& Berthel., Hist. Nat. Iles Canaries 2(3): 253. 1847 - Type: E. aphylla Brouss. ex Willd.

Shrubs, succulent to semisucculent or subwoody, muchbranched or dendroid, branches pencil-like or slightly to strongly clavate and often green (chlorophyllous), glabrous. Stem leaves alternate, well-developed, rarely absent or reduced to minute, caducous leaf rudiments, usually deciduous during the dry season, lanceolate-spatulate or narrowly ovate, margin entire, venation pinnate, prominent to inconspicuous. Raylet leaves 2 , free or connate. Cyathial glands 4 or 5 , rarely $6-8$, suborbicular, trapezoid or elliptic, margin entire, without or with 2-horn-like appendages. Capsule furrowed, smooth or weakly papillose on the rims, glabrous. Seeds ovoid to subovoid, from nearly smooth to deeply and irregularly furrowed, brownish to grayish, carunculate. $2 n=20$. 
We defined two subsections within E. sect. Aphyllis that are based on their morphological differentiation and their clear geographical separation. The disjunct distribution of this section (with species from Africa, the southern Arabian Peninsula, Madagascar, and Macaronesia) has been explained by a vicariance event that occurred in the ancient subtropical flora distributed in northern Africa that was fragmented due to aridification during the Miocene-Pliocene (Axelrod \& Raven, 1978; Quezel, 1979; Bramwell, 1985; Andrus \& al., 2004; Thiv \& al., 2010). Dispersal has also been suggested as a plausible explanation of the so-called "Rand flora" pattern that is well known in Euphorbia (Barres \& al., 2011; Bruyns \& al., 2011) and has also been documented in a number of other plant groups (Levyns, 1964; Galley \& al., 2007; Sanmartín \& al., 2010).

\section{Key to the subsections of Euphorbia sect. Aphyllis}

1a. Mostly leafy shrubs with leaves in dense, terminal rosettes (leafless in E. aphylla); branching usually pseudoverticillate or pseudodichotomous; pleiochasium with rays of similar length and all cyathia alike and bisexual; Macaronesian islands, southern Portugal, and coast of Morocco and Western Sahara ... 17a. E. subsect. Macaronesicae

1b. Mostly leafless shrubs (leafy in E. usambarica), leaves when present not in dense terminal rosettes; branching mostly lateral, rarely pseudodichotomous; pleiochasia with an initial shorter, caducous ray that bears a different cyathium from the rest, usually larger, sometimes functionally male, and with at least one more gland than the surrounding cyathia; mainland Africa (excluding northwestern Africa), southern Arabian Peninsula, and Madagascar .................... 17b. E. subsect. Africanae

17a. Euphorbia subsect. Macaronesicae Molero \& Barres, subsect. nov. - Type: E. regis-jubae Webb \& Berthel. Dendroid to hemispherical shrubs with pseudoverticillate or pseudodichotomous branching. Leaves well developed (absent or reduced to minute, caducous leaf rudiments in E. aphylla), usually deciduous and mainly present during the rainy season (very early deciduous in $E$. lamarckii), persistent in laurel forest species, spirally distributed on young stems, ending in a dense terminal rosette; dense leaf-scars present but not very prominent. Pleiochasia with 3-9(-14) rays, each of these (0)1-2(3) times dichotomous or trichotomous, all rays of the same length and persistent, each with the same kind of cyathia, always bisexual, with (4)5 glands. Capsule as wide as or wider than long. Seeds ovoid to subtetragonous, nearly smooth to irregularly furrowed. $2 n=20$.

Included species (11). - E. anachoreta Svent., E. aphylla Brouss. ex Willd., E. atropurpurea Brouss., E. berthelotii Bolle ex Boiss., E. bourgaeana J. Gay ex Boiss., E. bravoana Svent., E. lamarckii Sweet, E. pedroi Molero \& Rovira, E. piscatoria Aiton, E. regis-jubae Webb \& Berthel., E. tuckeyana Steud. ex Webb.

Distribution and habitat. - Macaronesian islands (except for the Azores), southern coast of Portugal, and the Atlantic coast of Morocco and Western Sahara. Mostly thermophilous or xerophilous species growing on volcanic soils near arid coasts ("malpais") on the Canary Islands, Selvagens Islands and Madeira and from the two Macaronesian enclaves in mainland Portugal and Morocco, from sea level to $1600(-2200) \mathrm{m}$. Some mesophilous species (E. atropurpurea, E. bravoana, E. bourgaeana) occur in evergreen laurel forest on the Canary Islands between 400 and $1600 \mathrm{~m}$. Euphorbia aphylla is a distinctive xerophytic-halophytic species, growing from sea level to $600 \mathrm{~m}$ elevation on coastal cliffs and rocky outcrops of the Canary Islands. On Cape Verde, the xerophilous to mesophilous E. tuckeyana occurs at elevations of 200-2200 m.

Although Boissier included some of the species of this subsection in E. subsect. Pachycladae (Boissier, 1862), this was a polyphyletic group that was eventually typified by Wheeler (1943) with E. dendroides, a species that is now considered one of two species in E. sect. Pachycladae. Likewise, the single pencil-stemmed species in this section, E. aphylla, was included by Boissier (1862) in another polyphyletic mixture of species in Euphorbia sect. Tirucalli Boiss. However, the type of that section is E. tirucalli L. and belongs to E. subg. Euphorbia (Bruyns \& al., 2006; Dorsey \& al., 2013).

17b. Euphorbia subsect. Africanae Molero \& Barres, subsect. nov. - Type: E. mauritanica L.

Erect to scrambling, pencil-stemmed or leafy, semisucculent or nonsucculent shrubs, usually with green to gray-green stems, with lateral branching, rarely branching mainly from the base (E. stolonifera) or with dichotomous rebranching (E. usambarica). Leaves usually reduced, loosely distributed along stems (not in terminal rosettes on young stems), soon deciduous, but well-developed and persistent until fruiting in E. berotica, E. lateriflora, and E. usambarica; leaf scars prominent and usually becoming calloused. Pleiochasia with (1-)3-5(-8) rays, these unbranched or simply dichotomous, sometimes congested; central ray shorter and soon deciduous, with a bisexual cyathium or else a functionally male cyathium with (5)6-8(9) glands; lateral cyathia bisexual with 4 or 5 glands; raylet leaves small, soon deciduous. Capsule always wider than long. Seeds ovoid, nearly smooth to rugose or finely tuberculate-rugose. $2 n=20$.

Included species (12). - E. berotica N.E. Br., E. calamiformis P.R.O. Bally \& S. Carter, E. gossypina Pax, E. lateriflora Schumach., E. mauritanica L., E. nubica N.E. Br., E. orthoclada Baker, E. pachyclada S. Carter, E. papilionum S. Carter, E. schimperi C. Presl, E. stolonifera Marloth, E. usambarica Pax.

Distribution and habitat. - Africa, southern Arabian Peninsula, Socotra, and Madagascar. In northeastern Africa and Arabia, the thermophilous and xerophilous pencil-stemmed succulent shrubs grow in many arid to semi-arid habitats, such as open deciduous woodland or scrub, stony slopes with a sparse cover of low trees and succulents, or lightly wooded grasslands from 100-2300 m elevation. In southern Africa and Angola, E. berotica, E. mauritanica, and E. stolonifera grow on stony slopes or in flat, loamy to sandy areas and are usually associated with a low vegetation in which succulents predominate. Euphorbia mauritanica and E. stolonifera are both typical elements of the Succulent Karroo Biome of western South 
Africa and southern Namibia, although they are not restricted to that area. In central and eastern Africa, the mesophilous E. usambarica grows in the understory of fairly open montane forest and riverine forest, between 1000-2400 m. Finally, E. orthoclada grows in a variety of habitats on Madagascar.

Most species in E. subsect. Africanae are semisucculents where the leaves are soon deciduous and the photosynthetic functions of the plant are performed by the pencil-like, green stems. Euphorbia usambarica is markedly different from this in that it is a nonsucculent shrub with thin, sometimes drooping branches that rebranch dichotomously, persistent lanceolate leaves that leave no scars on the stems, and persistent bracts. However, the central male cyathium of each pleiochasium has 5 glands and is surrounded by rays with bisexual cyathia having 4 glands, which is consistent with its position in $E$. subsect. Africanae.

18. Euphorbia sect. Paralias Dumort., Fl. Belg.: $87.1827 \equiv$ Tithymalus subg. Paralias (Dumort.) Raf., Fl. Tellur. 4: 115. $1838 \equiv$ E. subg. Paralias (Dumort.) Prokh. in Komarov, Fl. URSS 14: 308. 1949 - Type: E. paralias L.

= Allobia Raf., Fl. Tellur. 4: 116. $1838-$ Type: A. portlandica

(L.) Raf. (三Euphorbia portlandica L.).

Perennial, biennial, and annual herbs, sometimes subwoody at the base, glabrous. Stem leaves alternate, linear oblong, oblanceolate, usually imbricate, margin entire, rarely semisucculent, venation mostly obscure (midrib sometimes prominent). Raylet leaves 2, free. Cyathial glands 4 ( 5 in E. trichotoma), semilunate or trapezoid to elliptic, margin entire or dentate, with 2 usually acute horn-like appendages. Capsule depressed globose, sometimes trilobed, conical or cylindrical, minutely rugose or granulate, sometimes smooth, glabrous. Seeds ovoid, usually subquadrangular in cross-section, reticulate-foveolate to almost smooth, grayish, carunculate. $2 n=16,18,22,40$.

Included species (12). - E. azorica Hochst. in M.A. Seubert, E. celerieri (Emb.) Emb. ex Vindt, E. deflexa Sibth. \& Sm., E. maresii Knoche, E. ledebourii Boiss., E. mazicum Emb. \& Maire, E. paralias L., E. portlandica L., E. reuteriana Boiss., E. segetalis L., E. taurinensis All., E. trichotoma Kunth.

Distribution and habitat. - Mediterranean region, Balkans, Caucasus, Macaronesia (including Azores), and the Caribbean; often in coastal sandy habitats but some species farther inland and upland.

19. Euphorbia sect. Tithymalus (Gaertn.) Roep. in Duby, Bot. Gall., ed. 2: 412. $1828 \equiv$ Tithymalus Gaertn., Fruct. Sem. Pl. 2: 115. 1790, nom. cons. $\equiv$ E. sect. Peplus Lázaro, Comp. Fl. Españ. 2: 282. 1896 - Type: E. peplus L. (三 T. peplus (L.) Gaertn.; type cons. for Tithymalus).

Annual or perennial herbs or subshrubs, glabrous or hairy, rarely papillose. Stem leaves alternate, orbicular to linear-lanceolate or spatulate, margin entire or rarely serrulate, venation pinnate, usually obscure (midrib usually prominent). Raylet leaves 2 , free or partially connate. Cyathial glands 4, oblong to crescent-shaped, margin entire or dentate/crenate, 2 hornlike appendages usually present. Capsule globose to oblongovoid, usually smooth or in some cases slightly puncticulate, glabrous or hairy, cocci rounded or winged. Seeds oblong to subovoid, pitted, sulcate, shallowly sculptured, or foveolate, rarely smooth, white, gray to brown, or mottled, carunculate. $2 n=16,28$.

Included species (35). - E. beamanii M.C. Johnst., E. brachycera Engelm., E. caudiculosa Boiss., E. chamaepeplus Boiss. \& Gaill., E. chamaesula Boiss., E. chiribensis V.W. Steinm. \& Felger, E. commutata Engelm. ex A. Gray, E. correllii M.C. Johnst., E. creberrima McVaugh, E. crenulata Engelm., E. cressoides M.C. Johnst., E. eggersii Urb., E. furcillata Kunth, E. greggii Engelm. ex Boiss., E. helleri Millsp., E. herniariifolia Willd., E. hieroglyphica Coss. \& Durieu ex Boiss., E. isaurica M.S. Khan, E. ivanjohnstonii M.C. Johnst., E. longecornuta S. Watson, E. longicruris Scheele, E. lurida Engelm., E. mcvaughiana M.C. Johnst., E. neilmuelleri M.C. Johnst., E. orizabae Boiss., E. peplidion Engelm., E. peplus L., E. pinkavana M.C. Johnst., E. promecocarpa Davis, E. punctata Delile, E. roemeriana Scheele, E. schizoloba Engelm., E. tetrapora Engelm., E. tuerckheimii Urb., E. yaquiana (Cockerell) Tidestr.

Distribution and habitat. - Seven species (E. caudiculosa, E. chamaepeplus, E. herniariifolia, E. hieroglyphica, E. isaurica, E. promecocarpa, E. punctata) are native to and restricted to the Old World from the eastern Mediterranean region to Iran and the Arabian Peninsula. The weedy E. peplus is also presumably native to the Mediterranean region but is now widespread worldwide. The remaining species are native to the New World (United States, Canada, Mexico, Central America, Hispaniola). Many of them are restricted to relatively high montane habitats, but others occur at lower elevations and are either widespread (e.g., E. commutata) or local (e.g., E. roemeriana, E. tetrapora).

Most of the Old World species are perennials and occur in arid habitats. The annual habit is more common in the New World group, which includes seven annual species. Euphorbia peplus and a few other Old World species have characteristic narrow wings on the capsules (Fig. 2K) and dorsally keeled seeds. In addition to the species listed above, there are at least five new North American species awaiting description (M. Mayfield, pers. comm.).

20. Euphorbia sect. Arvales (Geltman) Geltman, stat. nov. $\equiv$ E. subsect. Arvales Geltman in Novosti Sist. Vyssh. Rast. 32: 102. 2000 - Type: E. arvalis Boiss. \& Heldr.

Annual herbs, glabrous. Stem leaves alternate, linear or oblong to elliptic or obovate, margin entire or minutely serrate, venation mostly obscure (midrib sometimes prominent). Raylet leaves 2 , free. Cyathial glands 4, elliptic, margin entire, usually with 2 whitish, horn-like appendages. Capsule subspherical or ovoid, smooth, glabrous. Seeds subcylindrical to subovoid, subquadrangular or hexagonal in cross-section, longitudinally sulcate or irregularly tuberculate-rugulose, grayish or whitish, carunculate. $2 n=20,40$.

Included species (7). - E. arvalis Boiss. \& Heldr., E. aulacosperma Boiss., E. franchetii B. Fedtsch., E. heptapotamica Golosk., E. maddenii Boiss., E. normannii Schmalh. ex Lipsky, E. sulcata Lens ex Loisel. 
Distribution and habitat. - Mediterranean region and neighboring areas, Canary Islands, Iranian highlands, central Asia to northern Afghanistan, western China, and India; on open stony or gravelly slopes, in steppes and deserts, in fields and by roadsides.

The section includes two groups, one with hexagonal, longitudinally sulcate seeds (E. aulacosperma, E. maddenii, E. sulcata), and the other with subquadrangular, irregularly tuberculate-rugulose seeds (E. arvalis, E. franchetii, E. heptapotamica, E. normannii). Our phylogenetic results (Fig. 5) show that $E$. arvalis subsp. longistyla is more closely related to E. sulcata than to E. arvalis subsp. arvalis. This relationship is supported by geography, since E. sulcata and E. arvalis subsp. longistyla co-occur in southern Spain and Morocco, whereas E. arvalis subsp. arvalis is distributed from the Transcaucasus region to Iran. Further study is needed in this section to clarify species relationships and to resolve the status of $E$. arvalis subsp. longistyla.

21. Euphorbia sect. Esula (Pers.) Dumort., Fl. Belg.: 87. 1827 $\equiv$ E. subg. Esula Pers. (see p. 330) - Type: E. esula L.

= Euphorbia sect. Wentsai J.S. Ma \& C.Y. Wu in Collect. Bot. (Barcelona) 21: 116. 1993 - Type: E. yanjinensis W.T. Wang.

Perennial herbs or occasionally small shrubs, glabrous or hairy. Stem leaves alternate, linear to elliptic or ovate, margin entire, venation pinnate, mostly prominent. Raylet leaves 2 , free. Cyathial glands 4, semilunate or trapezoidal, margin entire, with 2 horn-like appendages. Capsule ovoid or nearly so, deeply trilobed, smooth or minutely granulate, glabrous or pilose. Seeds ovoid or oblong to subspherical, mostly smooth, rarely foveolate, grayish, carunculate. $2 n=18,20,36,40,56$, 60, 64.

Included species (96). - E. agraria M. Bieb., E. albanica N.E. Br., E. andrachnoides Schrenk, E. androsaemifolia Willd. ex Schlecht., E. astrachanica C.A. Mey. ex Trautv., E. borbonica Boiss., E. borealis Baikov, E. borodinii Sambuk, E. brevicornu Pax, E. buhsei Boiss., E. buschiana Grossh., E. caesia Kar. \& Kir., E. citrina S. Carter, E. crebrifolia S. Carter, E. cyparissias L., E. cyparissioides Pax, E. cyrtophylla (Prokh.) Prokh., E. daghestanica Geltman, E. dahurica Peschkova, E. daviesii E.A. Bruce, E. discolor Ledeb., E. dubovikii Oudejans, E. emirnensis Baker, E. epicyparissias (E. Mey. ex Klotzsch \& Garcke) Boiss., E. ericoides Lam., E. erythrina Link, E. esula L., E. filicina Port., E. foliosa N.E. Br., E. furcatifolia M.G. Gilbert, E. gayi Salis, E. genistoides P.J. Bergius, E. glauca G. Forst., E. glomerulans (Prokh.) Prokh., E. gmelinii Steud., E. graminifolia Vill., E. guntensis (Prokh.) Prokh., E. hebecarpa Boiss., E. iberica Boiss., E. imperfoliata Vis., E. irgisensis Litv., E. jaxartica (Prokh.) Krylov, E. kaleniczenkoi Czern., E. kansui S.L. Liou, E. kirimzjulica Stepanov, E. korshinskyi Geltman, E. kraussiana Bernh. ex Krauss, E. latifolia C.A. Mey. ex Ledeb., E. lenensis Baikov, E. leptocaula Boiss., E. lucida Waldst. \& Kit., E. lunulata Bunge, E. mandshurica Maxim., E. microcarpa (Prokh.) Krylov, E. muraltioides N.E. Br., E. nakaii Hurus., E. natalensis Bernh. ex Krauss, E. nevadensis Boiss. \& Reut., E. octoradiata H. Lév. \& Vaniot,
E. oidorrhiza Pojark., E. osyridea Boiss., E. ovata (E. Mey. ex Klotzsch \& Garcke) Boiss., E. pamirica (Prokh.) Prokh., E. pancicii Beck, E. pauciradiata Blatt., E. poecilophylla (Prokh.) Prokh., E. potaninii Prokh., E. pseudagraria P.A. Smirn., E. reineckei Pax, E. repetita Hochst. ex A. Rich., E. rossica P.A. Smirn., E. rothiana Spreng., E. ruscifolia (Boiss.) N.E. Br., E. salicifolia Host, E. sareptana Becker, E. saurica Baikov, E. schimperiana Scheele, E. sclerophylla Boiss., E. sewerzowii (Prokh.) Pavlov, E. sieboldiana C. Morren \& Decne., E. subcordata Ledeb., E. subtilis (Prokh.) Prokh., E. striata Thunb., E. talaina Radcl.-Sm., E. thyrsoidea Boiss., E. tongchuanensis C.Y. Wu \& J.S. Ma, E. tristis Besser, E. tshuiensis (Prokh.) Serg. ex Krylov, E. undulata M. Bieb., E. uralensis Fisch. ex Link, E. valliniana Belli, E. variabilis Ces., E. virgata Waldst. \& Kit., E. wellbyi N.E. Br., E. whyteana Bakerf., E. yanjinensis W.T. Wang.

Distribution and habitat. - Widespread in Europe and Asia, also in Africa, Madagascar, Réunion, Indonesia (Java), New Zealand, and Samoa, introduced in the New World and elsewhere; in meadows (lowland to montane), steppes, semideserts, riparian and littoral vegetation, sometimes in forests, weedy in arable lands, along roads and other disturbed areas.

Two species (E. tongchuanensis, E. yanjinensis) have in the past been separated into E. sect. Wentsai (Ma \& Wu, 1993). They are very similar to members of E. sect. Esula, although they are described as lacking bracteoles subtending the male flowers. This character, however, has not been examined carefully in all of the other species so we tentatively place both species here into $E$. sect. Esula.

Other species that have been suggested to belong in $E$. sect. Esula but which we have not been able to verify include $E$. ensifolia Baker from Madagascar, E. lioui C.Y. Wu \& S.J. Ma from northern China, E. ecorniculata Kitam. from Afghanistan, E. gulestanica Podlech from Afghanistan, and E. osyridiformis Parsa from Iran.

\section{- ACKNOWLEDGEMENTS}

We thank R. Becker, R. Gereau, F. Ismail, W. Kindeketa, F. Mbago, N. Mollel, A. Moller, G. Mwachala, H. Suleiman, and E. Wabuyele for facilitating fieldwork in South Africa, Tanzania, and Kenya, S. Ghazanfar and A. al-Jabri in Oman, and J. Caujapé Castells and A. Santos-Guerra in the Canary Islands. J.J. Aldasoro, P. CarrilloReyes, B.L. Dorsey, H.-J. Esser, Y. Etherington, P. Garnock-Jones, A. Gröger, J.W. Horn, W. Jin, A.L. Reina-G., V.W. Steinmann, A. Susanna, B.W. van Ee, T.R. van Devender, K.J. Wurdack, and the Royal Botanic Garden Edinburgh generously provided leaf material for analysis. We are grateful to the curators of the following herbaria who allowed us to examine their specimens: A, AA, ALTB, BCN, BM, BRI, COLO, E, EA, FRU, G, GH, IEB, JBSD, K, KSC, KW, LE, M, MA, MEL, MEXU, MHA, MICH, MO, MSB, MW, NHT, NY, ON, P, PRE, RSA, SGO, TASH, TUH, UC, UNIN, UPS, W, and WU. We are also grateful to J. Vicens for verifying specimen determinations. We thank H. Akhani for providing lab space to A. Pahlevani, and we thank H. Draheim, W. Jin, S. Pereira, and B. Wagner for assistance in the Berry lab. Funding was made available by the U.S. National 
Science Foundation through a Planetary Biodiversity Inventory Grant (DEB-0616533) to P.E. Berry, by the Spanish Ministry of Education and Science through project CGL2009-13322-C03-03 to L. Barres and J. Molero, and by the Russian Foundation for Basic Research through project 10-04-00290-a to D. Geltman and A. Kryukov.

\section{- LITERATURE CITED}

Andrus, N., Trusty, J., Santos-Guerra, A., Jansen, R.K. \& FranciscoOrtega, J. 2004. Using molecular phylogenies to test phytogeographical links between East/South Africa, Southern Arabia and the Macaronesian islands-a review, and the case of Vierea and Pulicaria sect. Vieraeopsis. Taxon 53: 333-346. http://dx.doi.org/10.2307/4135612

Axelrod, D.I. \& Raven, P.H. 1978. Late Cretaceous and Tertiary vegetation history of Africa. Pp. 77-130 in: Werger, M.J.A. (ed.), Biogeography and ecology of southern Africa. The Hague: W. Junk. http://dx.doi.org/10.1007/978-94-009-9951-0_5

Baikov, K.S. 2007. Molochai Severnoy Azii [Spurges of North Asia]. Novosibirsk: Nauka Publ.

Barres, L., Vilatersana, R., Molero, J., Susanna, A. \& GalbanyCasals, M. 2011. Molecular phylogeny of Euphorbia subg. Esula sect. Aphyllis (Euphorbiaceae) inferred from nrDNA and cpDNA markers with biogeographic insights. Taxon 60: 705-720.

Boissier, E. 1862. Euphorbieae. Pp. 3-188 in: Candolle, A.P. de (ed.), Prodromus systematis naturalis regni vegetabilis. Paris: Masson.

Bramwell, D. 1985. Contribución a la biogeografia de las Islas Canarias. Bot. Macaronés., IV Ci. 14: 3-34.

Bruyns, P.V., Mapaya, R.J. \& Hedderson, T. 2006. A new subgeneric classification for Euphorbia (Euphorbiaceae) in southern Africa based on ITS and psbA-trnH sequence data. Taxon 55: 397-420. http://dx.doi.org/10.2307/25065587

Bruyns, P.V., Klak, C. \& Hanáček, P. 2011. Age and diversity in Old World succulent species of Euphorbia (Euphorbiaceae). Taxon 60: $1717-1733$.

Carter, S. 2002. Euphorbiaceae. Pp. 99-230 in: Eggli, U. (ed.), Illustrated handbook of succulent plants. Dicotyledons. Berlin: Springer.

DiTomaso, J.M. \& Healy, E.A. 2007. Weeds of California and other Western States, vol. 1, Aizoaceae-Fabaceae. University of California, Agriculture and Natural Resources, Publication 3488. Oakland: University of California.

Dorsey, B.L., Haevermans, T., Aubriot, X., Morawetz, J.J., Riina, R., Steinmann, V.W. \& Berry, P.E. 2013. Phylogenetics, morphological evolution, and classification of Euphorbia subgenus Euphorbia. Taxon 62: 291-315. [this issue]

Esser, H.-J., Berry, P.E. \& Riina, R. 2009. EuphORBia: A global inventory of the spurges. Blumea 54: 11-12. http://dx.doi.org/10.3767/000651909X474023

Frajman, B. \& Schönswetter, P. 2011. Giants and dwarfs: Molecular phylogenies reveal multiple origins of annual spurges within Euphorbia subg. Esula. Molec. Phylogen. Evol. 61: 413-424. http://dx.doi.org/10.1016/j.ympev.2011.06.011

Galley, C., Bytebier, B., Bellstedt, D.U. \& Linder, H.P. 2007. The Cape element in the Afrotemperate flora: From Cape to Cairo? Proc. Roy. Soc. London, Ser. B, Biol. Sci. 274: 535-543. http://dx.doi.org/10.1098/rspb.2006.0046

Geltman, D.V. 2005. Vidy podsektsii Conicocarpae sektsii Paralias roda Euphorbia (Euphorbiaceae) vo flore Sredney Azii i Iranskogo nagor'ya [Species of the genus Euphorbia section Paralias subsection Conicocarpae (Euphorbiaceae) in the flora of Middle Asia and Iranian highlands]. Bot. Zhurn. (Moscow \& Leningrad) 91: 1097-1106.

Geltman, D.V. 2009. Konspekt sektsii Chamaebuxus Lázaro roda Euphorbia L. (Euphorbiaceae) [Conspectus of Euphorbia section Chamaebuxus Lázaro]. Novosti Sist. Vyssh. Rast. 40: 109-163.
Giner, J.L., Berkowitz, J.D. \& Andersson, T. 2000. Nonpolar components of the latex of Euphorbia peplus. J. Nat. Prod. (Lloydia) 63: 267-269. http://dx.doi.org/10.1021/np990081g

Hartwell, J.L. 1969. Plants used against cancer: A survey. Lloydia 32: $153-205$.

Hörandl, E. \& Emadzade, K. 2012. Evolutionary classification: A case study on the diverse plant genus Ranunculus L. (Ranunculaceae). Perspect. Pl. Ecol. Evol. Syst. 14: 310-324. http://dx.doi.org/10.1016/j.ppees.2012.04.001

Horn, J.W., Van Ee, B.W., Morawetz, J.J., Riina, R., Steinmann, V.W., Berry, P.E. \& Wurdack, K.J. 2012. Phylogenetics and the evolution of major structural characters in the giant genus $\mathrm{Eu}$ phorbia L. (Euphorbiaceae). Molec. Phylogen. Evol. 63: 305-326. http://dx.doi.org/10.1016/j.ympev.2011.12.022

Huelsenbeck, J.P. \& Ronquist, F. 2001. MRBAYES: Bayesian inference of phylogenetic trees. Bioinformatics 17: 754-755. http://dx.doi.org/10.1093/bioinformatics/17.8.754

Katoh, K., Kuma, K.-I., Toh, H. \& Miyata, T. 2005. MAFFT version 5: Improvement in accuracy of multiple sequence alignment. Nucl. Acids Res. 33: 511-518. http://dx.doi.org/10.1093/nar/gki198

Khan, M.S. 1964. Taxonomic revision of Euphorbia in Turkey. Notes Roy. Bot. Gard. Edinburgh 25: 71-161.

Kryukov, A.A., Geltman, D.V., Machs, E.M. \& Rodionov, A.V. 2010. Filogeniya vidov podroda Esula roda Euphorbia (Euphorbiaceae) po resultatam sravnitelnogo analiza posledovatelnostey rayona ITS1-5.8S rDNA-ITS2 [Phylogeny of Euphorbia subgenus Esula (Euphorbiaceae) inferred on the sequences of ITS1-5.8S rDNAITS2]. Bot. Zhurn. (Moscow \& Leningrad) 95: 801-819.

Levyns, M.R. 1964. Migrations and origin of the Cape flora. Trans. Roy. Soc. South Africa 37: 85-107. http://dx.doi.org/10.1080/00359196409519059

Linnaeus, C. 1753. Species plantarum, vol. 1. Stockholm: impensis Laurentii Salvii.

Ma, J.S. \& Wu, C.Y. 1993. A synopsis of Chinese Euphorbia L. s.l. (Euphorbiaceae). Collect. Bot. (Barcelona) 21: 97-120.

Maddison, D.R. \& Maddison, W.P. 2005. MacClade 4.08: An analysis of phylogeny and character evolution. Sunderland, Massachusetts: Sinauer.

Molero, J., Garnatje, T., Rovira, A., Garcia-Jacas, N. \& Susanna, A. 2002. Karyological evolution and molecular phylogeny in Macaronesian dendroid spurges (Euphorbia subsect. Pachycladae). Pl. Syst. Evol. 231: 109-132. http://dx.doi.org/10.1007/s006060200014

Olmstead, R.G. \& Sweere, J.A. 1994. Combining data in phylogenetic systematics: An empirical approach using 3 molecular data sets in the Solanaceae. Syst. Biol. 43: 467-481. http://dx.doi.org/10.1093/sysbio/43.4.467

Pahlevani, A.H. \& Akhani, H. 2011. Seed morphology of Iranian annual species of Euphorbia (Euphorbiaceae). Bot. J. Linn. Soc. 167: 212-234. http://dx.doi.org/10.1111/j.1095-8339.2011.01165.x

Pahlevani, A.H., Geltman, D. \& Riina, R. 2011. Taxonomic revision of Euphorbia subsect. Myrsiniteae Boiss. for the flora of Iran. Ann. Bot. Fenn. 48: 483-493. http://dx.doi.org/10.5735/085.048.0606

Park, K.R. \& Jansen, R.K. 2007. A phylogeny of Euphorbieae subtribe Euphorbiinae (Euphorbiaceae) based on molecular data. J. Pl. Biol. 50: 644-649. http://dx.doi.org/10.1007/BF03030608

Posada, D. 2008. jModelTest: Phylogenetic model averaging. Molec. Biol. Evol. 25: 1253-1256. http://dx.doi.org/10.1093/molbev/msn083

Prokhanov, Y.I. 1933. Sistematichesky obzor molochaev Sredney Azii [Systematic review of spurges of Middle Asia]. Moscow-Leningrad: Gosudarstvennoe khimiko-tekhnicheskoe izdatel'stvo.

Prokhanov, Y.I. 1949. Euphorbia L. Pp. 304-495 in: Komarov, V.L. (ed.), Flora SSSR, vol. 14. Moscow, Leningrad: Izdatel'stvo Akademii nauk SSSR.

Prokhanov, Y.I. 1964. Konspekt sistemy molochaev SSSR. Dobavleniya i izmenenia [Conspectus of the system of spurges of the USSR. Additions and changes]. Novosti Sist. Vyssh. Rast. 1: 226-237. 
Quezel, P. 1979. Analysis of the flora of Mediterranean and Saharan Africa. Ann. Missouri Bot. Gard. 65: 479-534. http://dx.doi.org/10.2307/2398860

Radcliffe-Smith, A. 1982. Euphorbia L. Pp. 571-630 in: Davis, P.H. (ed.), Flora of Turkey and the East Aegean Islands, vol. 7. Edinburgh: Royal Botanic Garden.

Rambaut, A. \& Drummond, A. 2007. Tracer, version 1.4. Computer program and documentation distributed by the author, http://beast .bio.ed.ac.uk/Tracer

Ramsay, J.R., Suhrbier, A., Aylward, J.H., Ogbourne, S., Cozzi, S.J., Poulsen, M.G., Baumann, K.C., Welburn, P., Redlich, G.L. \& Parsons, P.G. 2011. The sap from Euphorbia peplus is effective against human nonmelanoma skin cancers. Brit. J. Dermatol. 164: 633-636.

Riina, R. \& Berry, P.E. 2012a. Euphorbia Planetary Biodiversity Inventory website. http://euphorbiaceae.org/pages/data_portal.html (accessed July 2012).

Riina, R. \& Berry, P.E. (coord.) 2012b. Euphorbia Planetary Biodiversity Inventory database. http://www.tolkin.org/projects/72 (accessed July 2012).

Ronquist, F. \& Huelsenbeck, J.P. 2003. MrBayes 3: Bayesian phylogenetic inference under mixed models. Bioinformatics 19: 1572-1574. http://dx.doi.org/10.1093/bioinformatics/btg180

Salmaki, Y., Zarre, S., Esser, H.J. \& Heubl, G. 2011. Seed and gland morphology in Euphorbia (Euphorbiaceae) with focus on their systematic and phylogenetic importance, a case study in Iranian highlands. Flora 206: 957-973. http://dx.doi.org/10.1016/j.flora.2011.07.005

Sanmartín, I., Anderson, C.L., Alarcon, M., Ronquist, F. \& Aldasoro, J.J. 2010. Bayesian island biogeography in a continental setting: The Rand Flora case. Biol. Lett. 6: 703-707. http://dx.doi.org/10.1098/rsbl.2010.0095

Schmelzer, G.H. \& Gurib-Fakim, A. (eds.) 2008. Plant resources of tropical Africa 11(1). Medicinal plants 1. Wageningen: PROTA Foundation; Leiden: Backhuys; Wageningen: CTA.

Shaw, J., Lickey, E.B., Schilling, E.E. \& Small, R.L. 2007. Comparison of whole chloroplast genome sequences to choose noncoding regions for phylogenetic studies in angiosperms: The tortoise and the hare III. Amer. J. Bot. 94: 275-288. http://dx.doi.org/10.3732/ajb.94.3.275

Simmons, M.P. 2004. Independence of alignment and tree search. Molec. Phylogen. Evol. 31: 874-879. http://dx.doi.org/10.1016/j.ympev.2003.10.008

Stamatakis, A. 2006. RAxML-VI-HPC: Maximum likelihood-based phylogenetic analyses with thousands of taxa and mixed models. Bioinformatics 22: 2688-2690.

http://dx.doi.org/10.1093/bioinformatics/btl446

Steinmann, V.W. \& Porter, J.M. 2002. Phylogenetic relationships in Euphorbieae (Euphorbiaceae) based on ITS and $n d h F$ sequence data. Ann. Missouri Bot. Gard. 89: 453-490. http://dx.doi.org/10.2307/3298591

Swofford, D.L. 2003. PAUP*: Phylogenetic analysis using parsimony (*and other methods), version 4. Sunderland, Massachusetts: Sinauer.

Thiv, M., Thulin, M., Hjertson, M., Kropf, M. \& Linder, H.P. 2010. Evidence for a vicariant origin of Macaronesian-Eritreo/Arabian disjunctions in Campylanthus Roth (Plantaginaceae). Molec. Phylogen. Evol. 54: 607-616. http://dx.doi.org/10.1016/j.ympev.2009.10.009

Wheeler, L.C. 1943. The genera of living Euphorbieae. Amer. Midl. Naturalist 30: 456-503. http://dx.doi.org/10.2307/2421292

Yang, Y. \& Berry, P.E. 2011. Phylogenetics of the Chamaesyce Clade (Euphorbia, Euphorbiaceae): Reticulate evolution and longdistance dispersal in a prominent C4 lineage. Amer. J. Bot. 98: $1486-1503$.

Yang, Y., Riina, R., Morawetz, J.J., Haevermans, T., Aubriot, X. \& Berry, P.E. 2012. Molecular phylogenetics and classification of Euphorbia subgenus Chamaesyce (Euphorbiaceae). Taxon 61: 764-789. http://dx.doi.org/10.3732/ajb.1000496

Zimmermann, N.F.A., Ritz, C.M. \& Hellwig, F.H. 2010. Further support for the phylogenetic relationships within Euphorbia L. (Euphorbiaceae) from nrITS and trnL-trnF IGS sequence data. Pl. Syst. Evol. 286: 39-58. http://dx.doi.org/10.1007/s00606-010-0272-7 